\title{
Lost Landscape: A Combination of LiDAR and APSFR Data to Locate and Contextualize Archaeological Sites in River Environments
}

\author{
Esther Rodríguez González * (D), Pablo Paniego Díaz and Sebastián Celestino Pérez
}

\section{check for}

updates

Citation: Rodríguez González, E.; Paniego Díaz, P.; Celestino Pérez, S. Lost Landscape: A Combination of LiDAR and APSFR Data to Locate and Contextualize Archaeological Sites in River Environments. Remote Sens. 2021, 13, 3506. https:// doi.org/10.3390/rs13173506

Academic Editors: Antonio

Monterroso Checa and Dimitrios D. Alexakis

Received: 16 June 2021

Accepted: 31 August 2021

Published: 3 September 2021

Publisher's Note: MDPI stays neutral with regard to jurisdictional claims in published maps and institutional affiliations.

Copyright: (c) 2021 by the authors. Licensee MDPI, Basel, Switzerland. This article is an open access article distributed under the terms and conditions of the Creative Commons Attribution (CC BY) license (https:// creativecommons.org/licenses/by/ $4.0 /)$.
Instituto de Arqueologia (CSIC_Junta de Extremadura), 06800 Mérida, Spain; pablo.paniego@iam.csic.es (P.P.D.); scelestino@iam.csic.es (S.C.P.)

* Correspondence: esther.rodriguez@iam.csic.es

\begin{abstract}
Over the last few decades, river landscapes have been significantly transformed as a result of increased human impact. This transformation is evident in areas such as the middle Guadiana basin, where the impact of both agricultural and hydraulic infrastructures has led to the decontextualization of archaeological sites, resulting in a disconnection between archaeological sites and their own physical environment. In order to analyse the location and geographic contexts of sites from the first Iron Age in the middle Guadiana basin and to detect the existence of human settlement patterns, we designed a methodological approach that combines LiDAR and APSFR data (areas with potential significant flood risk). The main purpose of this method is to detect flood areas and assess the relationship between them and archaeological sites. The result allowed us to obtain a clearer understanding of these societies, their knowledge of the physical environment, and the causes and reasons behind their occupation of certain sites. The validation of the results demonstrated the versatility of this methodological approach, which can be extrapolated to analysing other regions and historical periods.
\end{abstract}

Keywords: LiDAR; potential flood risk; aerial archaeology; landscape archaeology; Tartessos; middle Guadiana basin

\section{Introduction}

The middle basin of the River Guadiana is an extensive area in the southwest of the Iberian Peninsula (Figure 1). It is structured around one of the main rivers of the peninsula, the Guadiana, which has a hierarchical network of tributaries that make it a fundamental artery of communication. The Guadiana is a low-lying river, shallow and easy to ford [1] (p. 29), making it an essential element that must be present in any analysis of ancient settlement in this region, given the migratory role the river played.

The fertility of the soil along the Guadiana River has favoured the occupation of the area from prehistoric times to the present day. However, local archaeological remains are in a poor state of preservation, due to agricultural work carried out in the area, which has led to the transformation of the landscape and the destruction of a large number of sites that are hidden under the current croplands. To overcome this situation, archaeologists use different landscape analysis tools and methodologies and remote sensing to facilitate our work by creating predictive models that give us a better understanding of how the landscape functioned in ancient times. The final aim of this work is to historically interpret the cartographic data to understand the relationships that ancient societies in the area had with the landscape in which they lived.

Given the close relationship between the Guadiana River and the settlement of this territory, in order to determine to what impact the river course has had on the settlements, and more specifically settlements from the first Iron Age, we designed an analysis strategy that incorporates data from the calculation of Areas with Potential Significant Flood Risk 
(APSFR) provided by the Guadiana River Hydrographic Confederation (CHG, dependent on the Spanish Ministry for Ecological Transition and Demographic Challenge); the traditional study carried out from the review of current and historical aerial photographs, and the spatial analysis made from the data provided by LiDAR flights.

Calculating the flood areas of the Guadiana riverbed and of some of its main tributaries allows us to delimit the area within which the course of the river shifted, hence the importance of this study and of the methodology it contains. With this image, we can determine the position of the sites with respect to the river, their distance or proximity, and estimate to what extent a site is impacted, or the symbolic significance of the places that were chosen to locate a site.

Although the working methodology presented in this article can be applied to any chronology, since the main variable of this formula is the location of the sites with respect to the watercourses in each historical moment, we selected the period comprising the first Iron Age in the middle Guadiana basin, between the seventh and fifth centuries BC. At this moment in time, the area was experiencing demographic growth as a result of the crisis that occurred in the heart of Tartessus, the Guadalquivir valley [2], which would result in the appearance of a new model of settlement that was unparalleled in other Mediterranean regions.

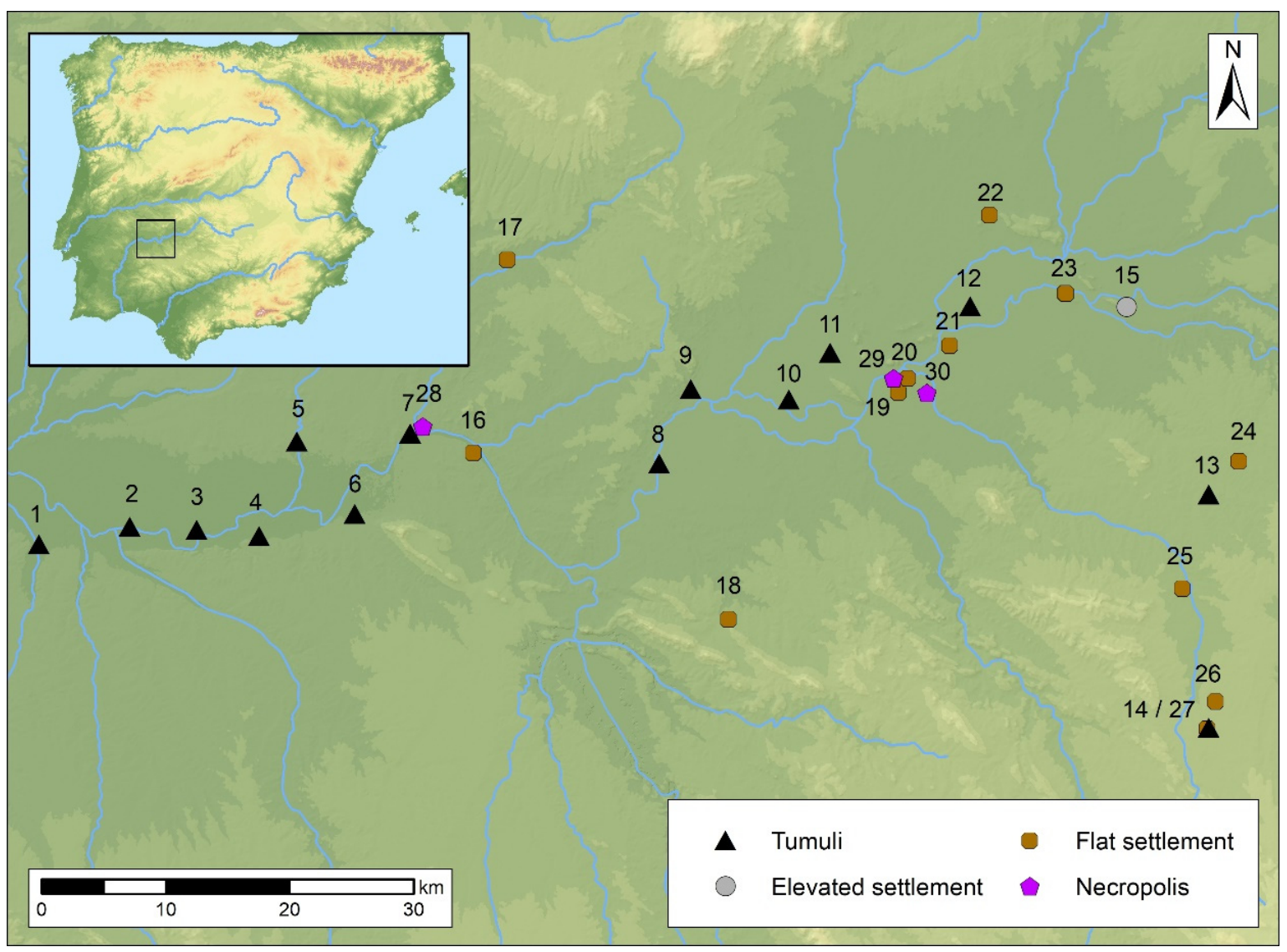

Figure 1. Map showing settlements in the middle Guadiana basin during the first Iron Age. 1. Huerta de Don Mateo; 2. Casas del Cerro de la Barca; 3. Cañada la Virgen; 4. Miraflores; 5. Lácara; 6. Turuñuelo de Mérida; 7. El Tiriñuelo; 8. Turuñuelo (Villagonzalo); 9. Las Madalenas; 10. Casas del Turuñuelo: 11. Las Lomas; 12. La Aliseda; 13. La Mata; 14. Cancho Roano; 15. El Tamborrio; 16. Escuela de Hostelería (Mérida); 17. El Chaparral; 18. El Palomar; 19. La Marquesa; 20. Medellín; 21. La Veguilla; 22. Cerro Manzanillo; 23. Cerro de la Barca-Torruco; 24. Media Legua; 25. La Carbonera; 26. La Mata de Cancho Roano; 27. Las Reyertas; 28. Necropolis of Aljucén; 29. Necropolis of El Pozo; 30. Necropolis of Valdelagrulla.

The population of the middle Guadiana basin during the first Iron Age was characterised by the presence of large structures at the confluence of the Guadiana and some 
of its main tributaries. There is only one exception to this pattern: the sites of Cancho Roano (Zalamea de la Serena, Badajoz, Spain) and La Mata (Campanario, Badajoz, Spain) located inland to the south of the river. All these structures have several characteristics in common, starting with the material used for their construction (adobe) and the way in which they were re-used. After their destruction and abandonment, these buildings were hidden under a large artificial mound that helped to conserve them until the present day. Along with the so-called Tartessian buildings hidden under tumuli, the settlement model is completed with the presence of settlements on high ground, village and farm-type sites on plains, and the necropolis (Figure 1). All of them form a hierarchical settlement model in which the Cancho Roano and Casas del Turuñuelo-type buildings play an important political and economic role [3].

Therefore, in order to demonstrate the effectiveness of the proposed methodological model, we selected several case studies that include examples corresponding to each of the settlement categories presented in the middle Guadiana basin. In the case of the necropolis, we present the results of El Pozo-Medellín, and the nearby settlement of Medellín (Badajoz, Spain); a village- or farm-type settlement represented by Cerro de la Barca-Torruco (Villanueva de la Serena, Badajoz, Spain), and an overview of the results obtained after applying the proposed methodology to the location of the so-called Tartessian buildings hidden under tumuli.

\section{The Middle Guadiana Basin: An Anthropized Territory}

In order to understand the importance of this study, it is important to consider the profound changes that the landscape of the central Guadiana basin has undergone over the last century, and how this process has affected the archaeological record.

The transformation of the Vegas del Guadiana experienced a major boost in the 1950s, when the General Economic and Social Development Plan for the Province of Badajoz, known as the Badajoz Plan, began to be implemented [4]. The work plan included the construction of hydraulic infrastructures, the adaptation of the necessary roads in the irrigation area, and the construction of new villages to house workers. The project included the irrigation of more than 120,000 hectares, the construction of 60 villages, and the planning of 8 reservoirs and 4 irrigation canals [5].

This colossal project entailed a radical change in the structure and image of the landscape, which went from being represented by large expanses of unirrigated land to being a green, irrigated landscape with alternating crops of tomato, rice and maize. This change also entailed the replacement of the native vegetation of the territory and the destruction of a large number of enclaves, irretrievable information that has left little trace in the archaeological record (Figure 2).

In addition to the transformation of the landscape, the construction of the reservoirs that currently regulate the Guadiana River has led to a reduction in its volume, the drying up of many of its tributaries that were operational in ancient times, and the displacement and channelling of others to use their waters for irrigating crops. The impact of this anthropization process is so considerable that in many cases, it is not even possible to locate the paleochannels of the rivers with the aid of current aerial photography, let alone to define the width of the original course of such important arteries as the Guadiana itself. The vast majority of these branches have been filled in with soil, and are currently occupied either by buildings or farmland (Figure 3 ).

Perhaps the closest example we have to appreciate the impact of the Badajoz Plan on cultural heritage is the Alqueva Dam Construction Plan in the Portuguese Alentejo region, inaugurated in 2002. This project has had an enormous impact on the landscape, the environment, and heritage assets; however, in contrast to the Alqueva Project, its execution included a programme to minimise the impact of the work on heritage assets, making it possible to document and safeguard a large number of settlements that were previously unknown, as well as to reduce the damage that this type of infrastructure causes to these remains [6]. 


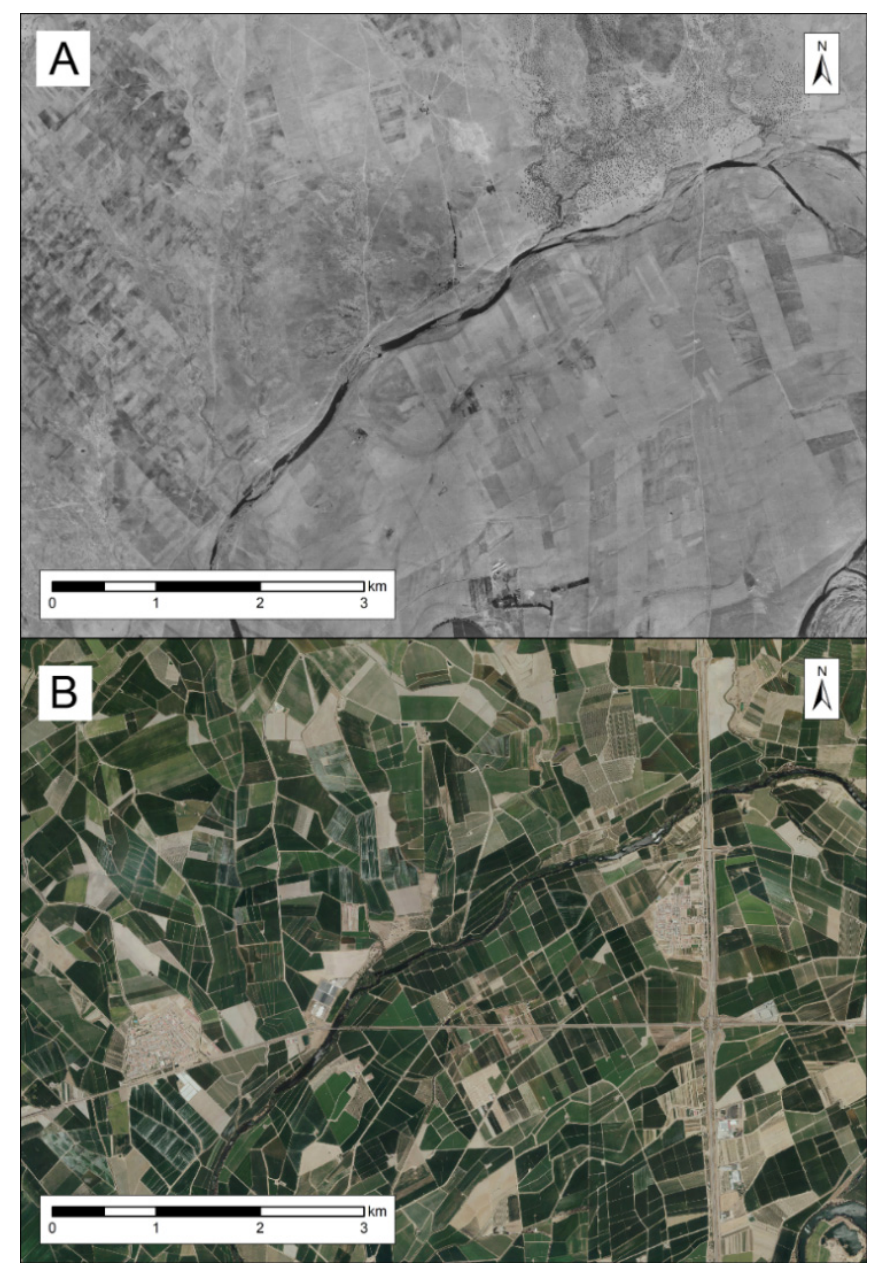

Figure 2. Aerial photographs of the section of the Guadiana between the Búrdalo and Ruecas tributaries showing the impact on the landscape caused by the implementation of the Badajoz Plan. (A) Photograph from the American flight of 1945/1946. (B) Still from the PNOA Máxima Actualidad.

In light of this, the main objective of this study is to contribute to the reconstruction and comprehension of the ancient landscape of the middle Guadiana basin. Only in this way will we be able to understand how this area was structured in ancient times, and assess the areas chosen for the location of the enclaves. We will also be able to evaluate the role the river played in the life of the societies that inhabited this area. What are the reasons or determining factors that led a group to select certain spaces as ideal sites to establish their settlements or necropolises?

To date, in order to achieve this objective and to approach the configuration of the landscape during antiquity, we resorted to different disciplines such as carpology and palynology, thanks to which we managed to identify the plant species found in this area during protohistory and to reconstruct, approximately, the palaeoenvironment of this territory during specific periods of history, such as the Iron Age [7]. We also undertook costly geomorphological work. In regions as transformed as the middle basin of the River Guadiana, this work must be accompanied by geotectonic analysis and OLS dating in order to date and reconstruct the structure of the geological model of the environment of the sites, or the terraces that the riverbeds have shaped over the years. These methods complicate the task of analysing large swathes of territory that may contain a significant number of sites. In this sense, for the time being in the middle Guadiana basin, we only carried out work in the area of Medellín, aimed at providing an approximate characterisation of its morphogenetics through the analysis with GIS tools. More detailed and complete field work is still pending that will make it possible to verify the data collected from the cartography $[8,9]$. 
Despite the changing and dynamic environment that characterises alluvial landscapes [10], it is not uncommon to use the current state of the landscape as a reference point and insert ancient populations into it, without assessing to what extent this space has been transformed over time. Detailed studies on these morphological changes have revealed how conditions in ancient times were different from those of today, and this is reflected in the detection, preservation and interpretation of sites, as well as in the documentation of flood events [11-13]. Unfortunately, studies of this kind are still lacking in the middle Guadiana basin.

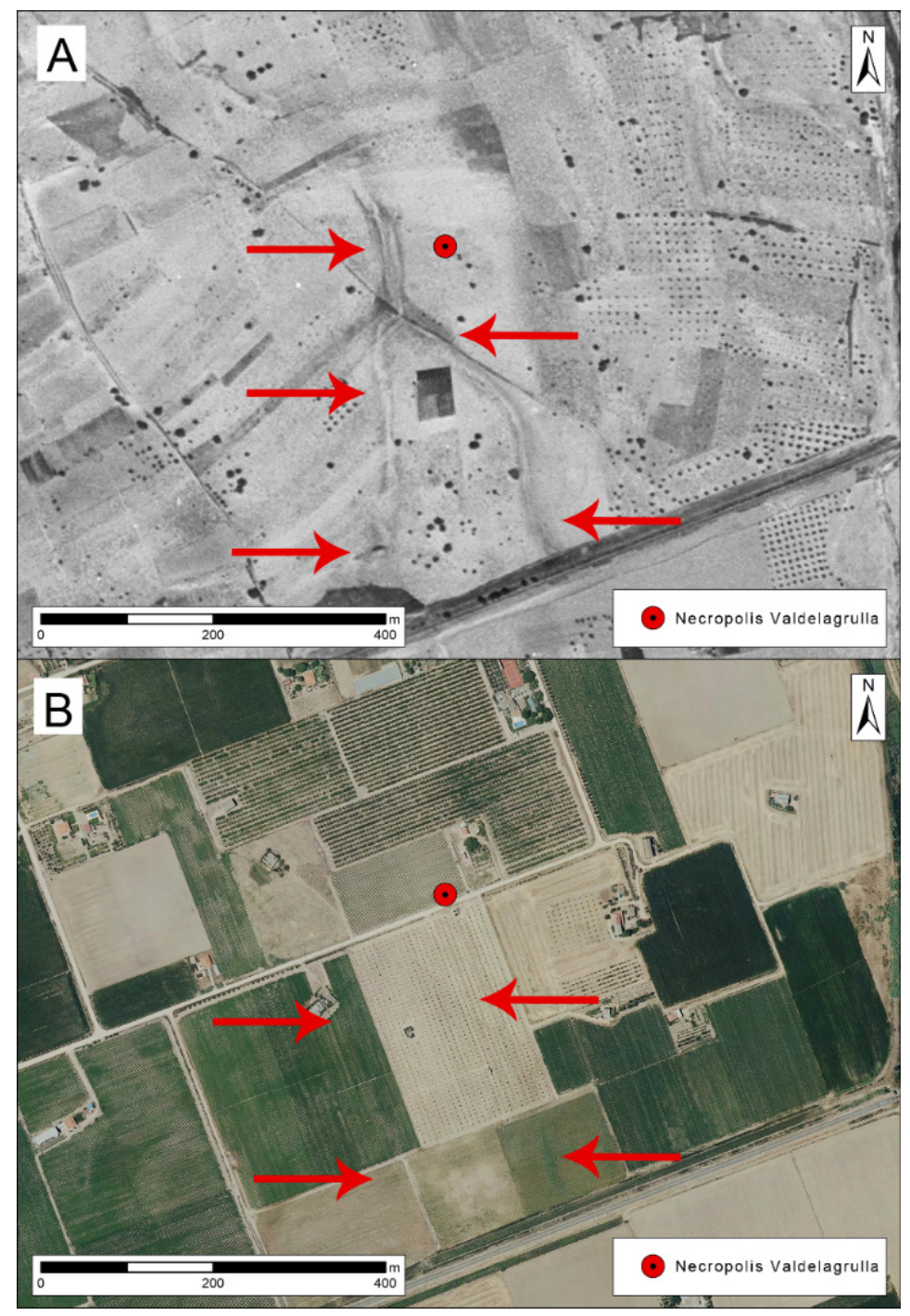

Figure 3. Comparison between a still from the American Flight of 1945/1946 (A) and an image corresponding to the PNOA Máxima Actualidad (B), where we can see the impact that the Badajoz Plan caused by cutting off paleochannels that were filled in and are now used as farming areas. The images show how two branches of the River Ortigas, a tributary of the Guadiana which flowed next to the Iron Age necropolis of Valdelagrulla, have been eliminated and are now occupied by orchards.

\section{Materials and Methods}

Traditionally, laboratory studies aimed at obtaining geomorphological data in certain geographic areas begin by comparing current aerial photographs, available in the National Aerial Orthophotography Plan (PNOA), with the photograms obtained from the American Flight, both Series A, taken between 1945 and 1946, and Series B, corresponding to the years 1956-1957. This latest series of photogrammetric flights contain the oldest images available of the Iberian Peninsula to determine the state and structure of the territory, in our specific 
case, prior to the implementation of the Badajoz Plan. As such, these are the images that come closest to the configuration that the territory would have had in ancient times.

As a complement to the comparative study between historical and current aerial photograms, we now present a new methodology in which two types of data are combined: LiDAR and the Areas with Potential Significant Flood Risk (APSFR), specifically those regions that are confined to the middle Guadiana river basin. The combination of both sources of information constitutes a new approach to geoarchaeological studies and the reconstruction of the paleo-landscape of a region, by allowing us to explore the configuration that fluvial arteries such as the Guadiana would have had in ancient times.

The use of LiDAR technology for the remote sensing of archaeological sites is a regular process in any archaeological project, whether in settlement or landscape studies [14-16]. This is due to the usefulness of the results provided by this tool in providing a precise image of the ground surface. Their level of detail makes it possible to document surface anomalies by algorithmically removing excess information, such as vegetation, which eliminates background noise when interpreting the presence of structures that belong to an archaeological site. The combination of Digital Elevation Models (DEMs) obtained from the processing and filtering of the point cloud acquired in the LiDAR flight with other tools, such as historical photography or filtering programmes that allow the presence of these anomalies in the terrain to be highlighted by shading, has emphasised the suitability of this technology within the field of archaeology. Its use for detecting sites is widely known [17]; however, there are fewer studies that use it for the topographical characterisation of a terrain or for the reconstruction of the ancient landscape [18-24].

In contrast to the usual use of LiDAR, data from the Preliminary Flood Risk Assessment (PFRA) have never been applied in western Europe in a study whose main objective is to reconstruct the ancient landscape. Mapping the regions defined as Areas of Potential Significant Flood Risk (APSFR) makes it possible to assess the expected depth in the event of flooding. These data, therefore, reflect the difference between the ground elevation at the time of the simulation and the height that the water would reach in the return periods.

In the data provided by the Guadiana River Basin Authority (CHG), three return periods are grouped together: T10, T100 and T500, pointing towards the existence of events that would potentially occur once every 10,100 or 500 years. Although this information is available for all the rivers of the Iberian Peninsula and in each region, they have a different recording pattern: the first floods documented by the CHG date back to the year $620 \mathrm{CE}$. Since that date, many events have been recorded, although data were not systematically gathered until 1935.

Although we are aware of the current nature of the data and the need to perform geomorphological studies in order to confirm the hypotheses, the use of ARSPI allows us to make a first contact with the ancient topography of the Guadiana and the areas through which the river and its tributaries must have flowed. At this point, it is necessary to highlight the restricted mobility of the Guadiana over the last few millennia due to the topography of the territory. This fact is reinforced by the absence of archaeological sites under alluvial formations, and also by the existence of remains of Roman bridges in Mérida and Medellín [25]. Although the construction of dams has affected the flow of the river and its regulation, the comparison with the photograms of the American Flight reveals the absence of significant changes in its course as a result of these works. In this way, ARSPI allows us, for example, to identify small clogged branches, and the area where the minor variations in their course occurred within a delimited area, possibly restricted to the T10 events.

As we can see below, the application of these data and their superimposition on a DTM allows us to accurately approach the palaeogeography of the Guadiana and some of its tributaries, in order to analyse the position that the sites of the first Iron Age occupied in the landscape, and how they may have been affected by flooding.

Fortunately, this archaeological work can be carried in Spain at no cost. All the data, both aerial photographs and LiDAR, are available to download from the server of the National Geographic Information Centre (CNIG), which depends on the National 
Geographic Institute (IGN) [26], as well as on the website of Spatial Data Infrastructures of Extremadura (IDEEx) [27], for the region in which our study area is located. Additionally, the Ministry for Ecological Transition and Demographic Challenge, within its Spatial Data Infrastructure (SDI), makes the APSFR cartography available to users [28]. In our specific case and for the drafting of this study, the APSFR information was provided directly by the Guadiana River Basin Authority (CHG).

The first step in our methodology (Figure 4) corresponds to downloading the data. Although the National Geographic Institute has two LiDAR flights, the first from 2008 to 2015 and the second from 2015 to the present day, we selected the data from the first flight for our study, as the second flight is not yet available for the entire peninsula. Although the IGN has the LiDAR data already classified, we selected the raw data in order to include the mechanisms that we use in the classification and transformation of the data and the subsequent obtaining of the Digital Terrain Model (DTM) in the workflow, which is mapping that serves as the basis for the visualisation of the results of our study.

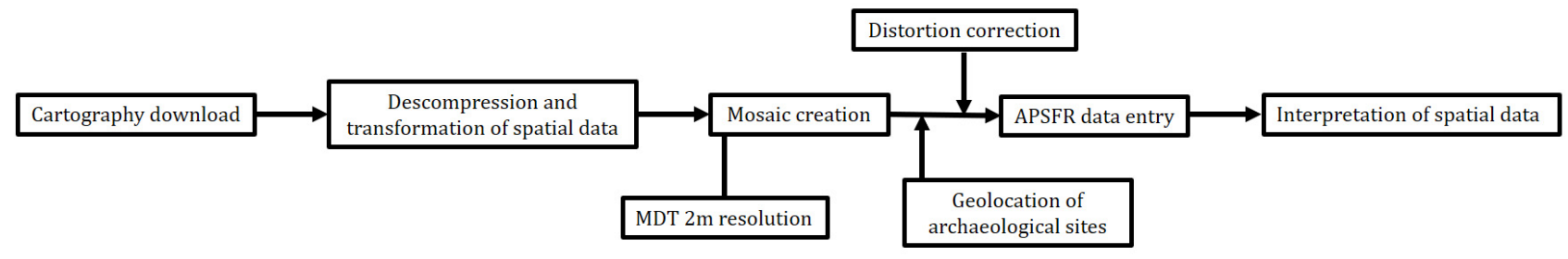

Figure 4. Workflow scheme.

The coverage corresponding to the first LiDAR flight has a resolution of $2 \mathrm{~m}^{2}$ of surface per point or 0.5 points $/ \mathrm{m}^{2}$. This resolution was more than enough to carry out the study proposed here, as it dealt with an extensive territory, but for the detection of certain archaeological remains, greater precision is required. The downloaded raw data are in .LAZ format, which requires decompression and transformation. For this purpose, we used the ARCGIS 10.5 program and the LASTool extension. The latter programme was developed by Martin Isenburg for LiDAR data processing and is free to download [29]. Of the tools contained in the LASTool extension, we used the Blast2dem extension. For its processing we left the default parameters, only modifying the triangulate variable, as our objective was to eliminate excess information, such as buildings or vegetation, in order to only obtain an image of the terrain surface. The final result is a Digital Elevation Model (DEM) which was exported in georeferenced tif format.

The spatial data provided by the IGN are distributed in several grids. Specifically, the data required for our study are distributed between MTN50 grids 776, 777, 778, 779, 752, 753, 754, 804 and 805, divided between zones 29 and 30 in an ETRS 89 coordinate system (Figure 5). In order to be able to work with a cartographic base that includes the entire territory under analysis, we have to paste the grids together and create a mosaic. To do this, we used another free downloadable tool, Relief Visualization Toolbox (RVT) [30], developed by the Research Centre of the Slovenian Academy of Science and Arts. The final result is a $2 \mathrm{~m}$ resolution DTM with hillshade from a single direction (Azimuth 315, Altitude 45). The aim of this analytical shading was to simulate an illumination of the terrain in order to enhance the visualisation of the relief.

The reclassified APSFR data were introduced on the base cartography that was created. The data provided by the CHG are in .shp polygon format. A 35\% transparency was applied to them so that the topography of the DTM used as a topographic base was visible. By incorporating the APSFR data into the DTM, we generated the definitive model that we could analyse to see how the river flood events affected the different sites, and compared the dispersion of these events with the historical photography in order to detect and define the presence of palaeo-channels that are currently non-existent or imperceptible.

By reviewing the resulting models, we detected some alterations in the final results that can be interpreted as distortions. This localised deformation in some of the case studies 
is due to the fact that the $\mathrm{CHG}$, when calculating the APSFR data and assessing the extent of each of the events, takes the current topography as a reference. Contemporary geographical features, many of them caused by agricultural activities, can be detected, which distort the result of the study, as they would not have existed in the past. For this reason, and with the aim of obtaining a vision as close as possible to the orography of the terrain during the first millennium BC, we drew up a protocol for correcting these distortions.

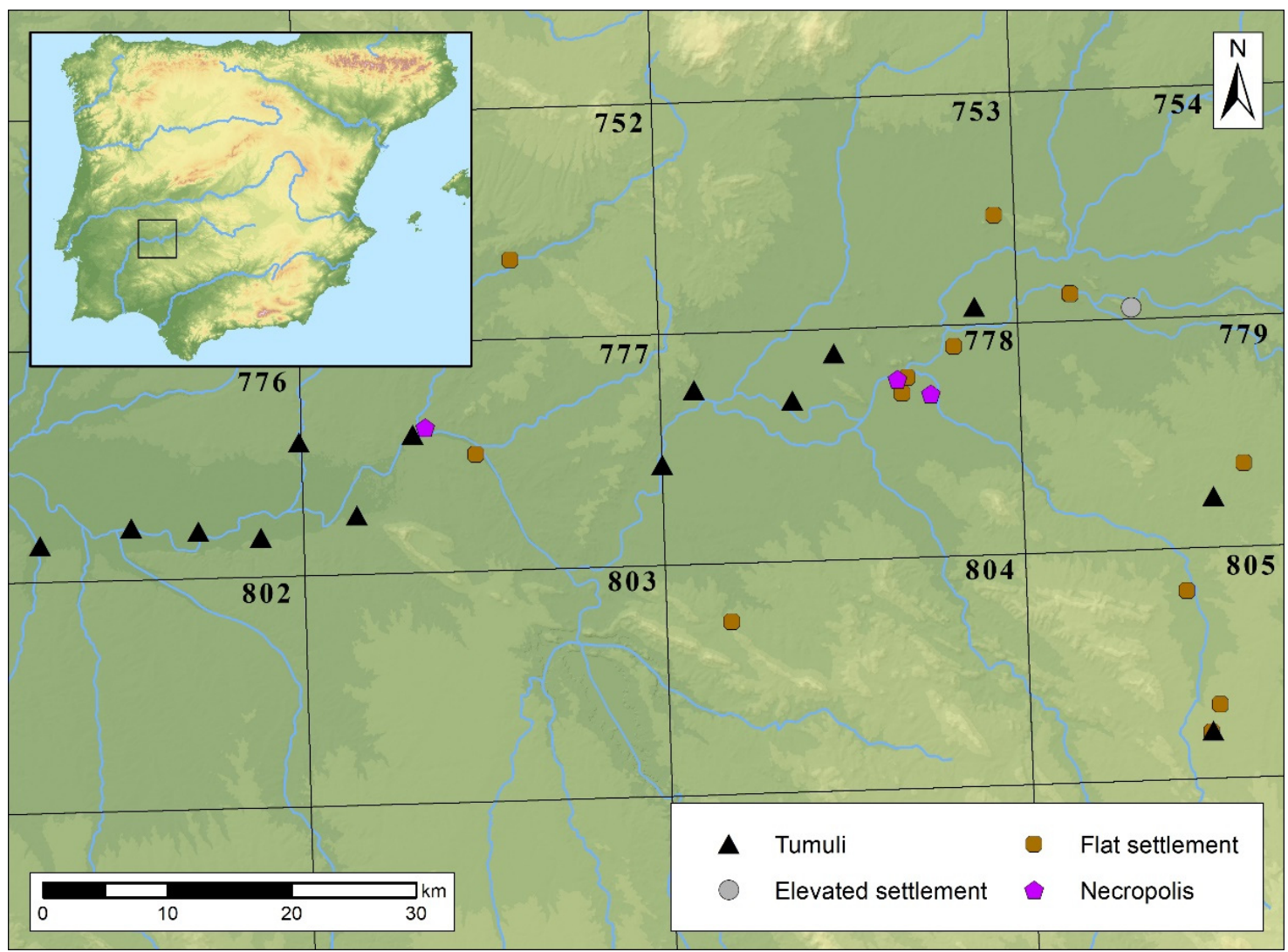

Figure 5. Mosaic of grids that contain our study territory. In order to have a basic cartography that covers the entire territory under analysis, we have to paste each one of the grids together.

The first cause of distortion are the plots of land used for growing maize at the time of the LiDAR flight. Given the density of this crop, it is impossible to eliminate this vegetation layer in the process of reclassifying the LiDAR data, because given its compactness, the tool identifies it as a solid surface, which takes the height of the maize at that moment as a reference. As this is sometimes up to two metres high, this distortion stops the flood event in its tracks, represented in the cartography with a square (Figure 6).

The second reason for distortion is due to the tumuli under which the Tartessian buildings are hidden. As we noted in the introduction to this work, one of the characteristics of these buildings is the way in which they were buried and hidden under a mound of earth which, like the corn, slows the spread of flooding events by having a level that is sometimes 5 or 6 metres above ground level (Figure 7). To see how the flood events directly affect the buildings, the mound must be eliminated, making this space's height equal to the height of the surrounding territory.

In order to eliminate both the vegetation of the plots sown with maize and the tumulus cover, we interpolated the values of the adjoining areas. The final result is a DTM in which the raster cells corresponding to the spaces occupied by the distortions in the base cartography have been reclassified with similar height values to those surrounding them, minimising the impact of the distortion. 


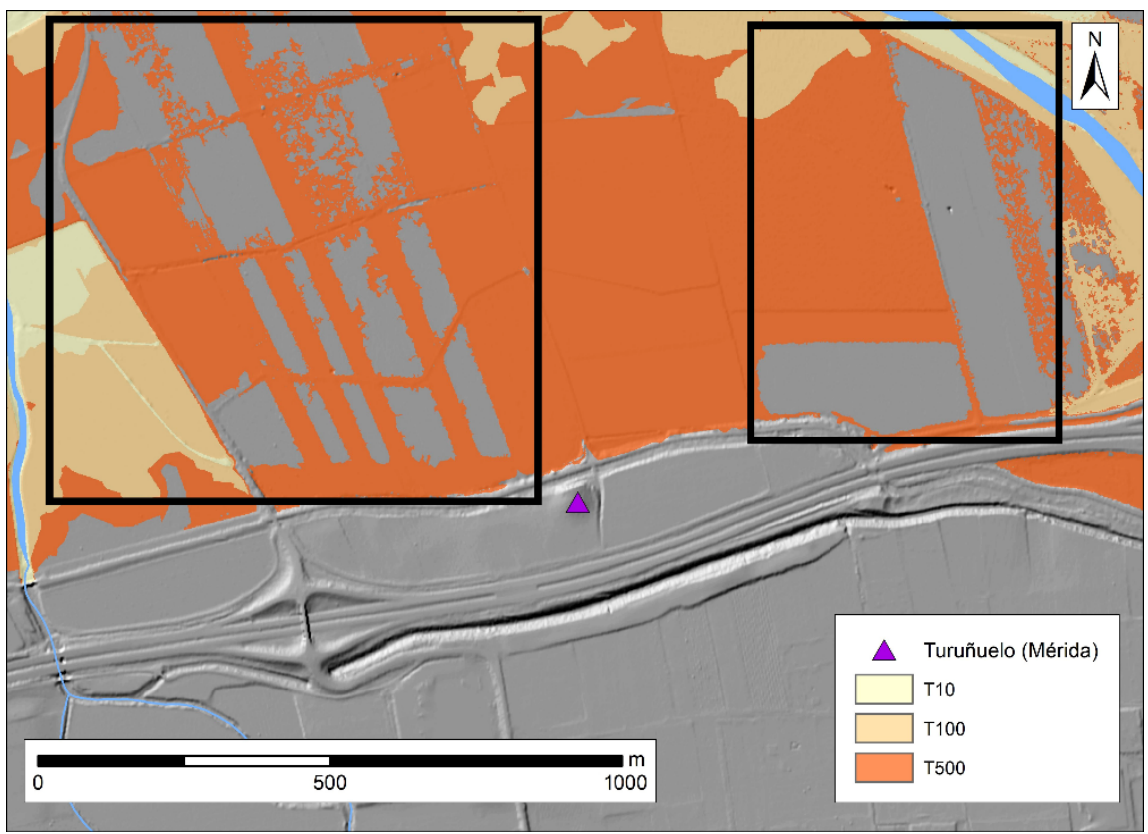

Figure 6. APSFR analysis corresponding to the territory where the Turuñuelo tumulus is located (Mérida, Badajoz, Spain). When observing the area affected by the T500 flood event, some information gaps can be detected (marked with a black rectangle), with a rectangular pattern, which are identified with the plots planted with maize. The density of this crop means that during the data interpolation exercise for the elimination of vegetation, the programme interprets it as a solid surface.

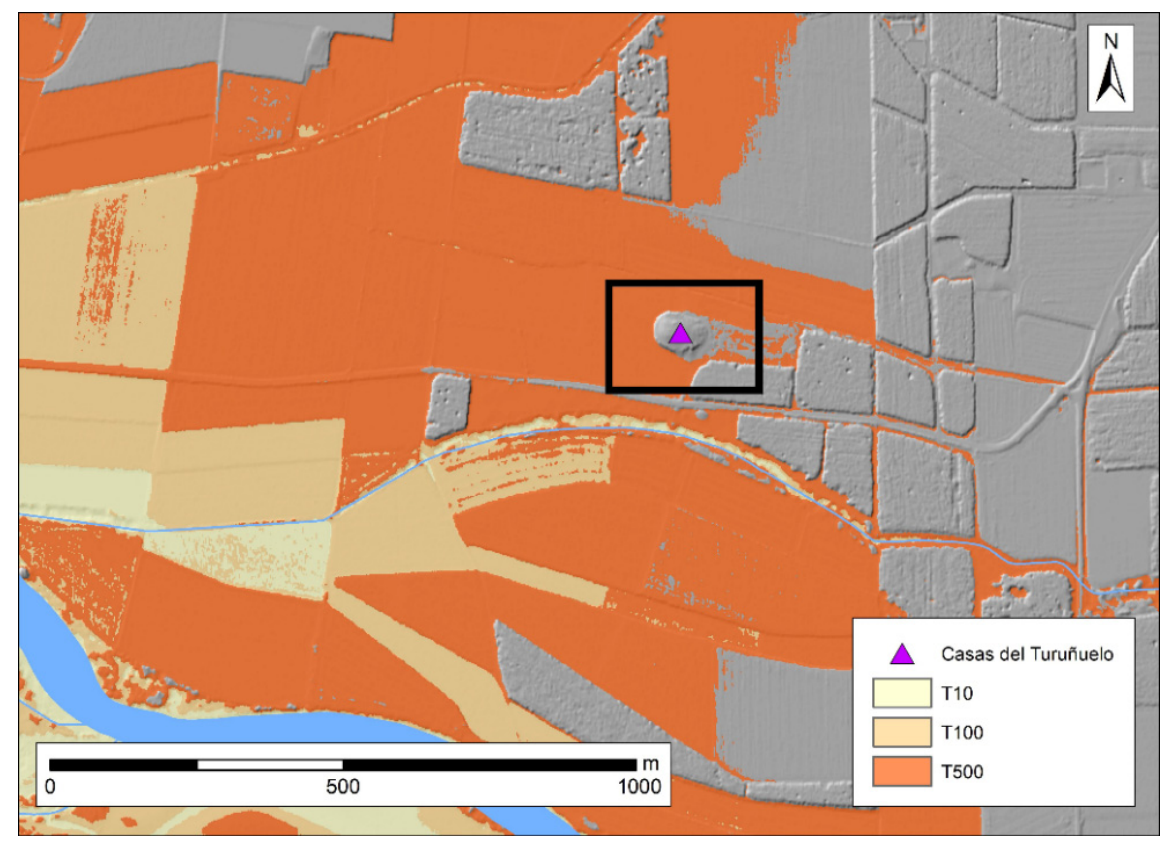

Figure 7. APSFR analysis corresponding to the territory where the Casas del Turunuelo burial mound is located (Guareña, Badajoz, Spain). Although the entire area to the west of the burial mound, including the site, is affected by the T500 flood event, the elevation of the burial mound under which the Tartessian building is hidden means that this part of the terrain is not affected.

Although this method allows us to eliminate the distortion generated by these topographic anomalies, which were absent in ancient times, the reprocessing of the DTM implies a loss of quality and accuracy in the final model. Therefore, we recommend that in the event of having to reclassify parts of the terrain to eliminate the distortions, these 
should be restricted as much as possible, only covering the areas affected by the distortions, in order to prevent the models from losing visualisation quality. To do this, it would be best to have the real elevation level of the site under study, i.e., its ground level, so that the APSFR analysis would approximate the real orography of the terrain, which would avoid having to make an interpolation. The modifications to the model would be restricted to reclassifying it using the value of the real elevation that the base of the site had when it was in use in ancient times, only having to remove the artificial tumulus that seals the site. However, and given that this would require the excavation of all the sites under study, which is quite complicated, the best option is to take the contour of the distortions with a differential GPS in the field, refining the area of affection and reclassification as much as possible. Finally, and in order to obtain the final model, both the DTM and the APSFR data are reclassified so that the flood data present their correct extension, thereby excluding modern-day obstacles (Figure 8).

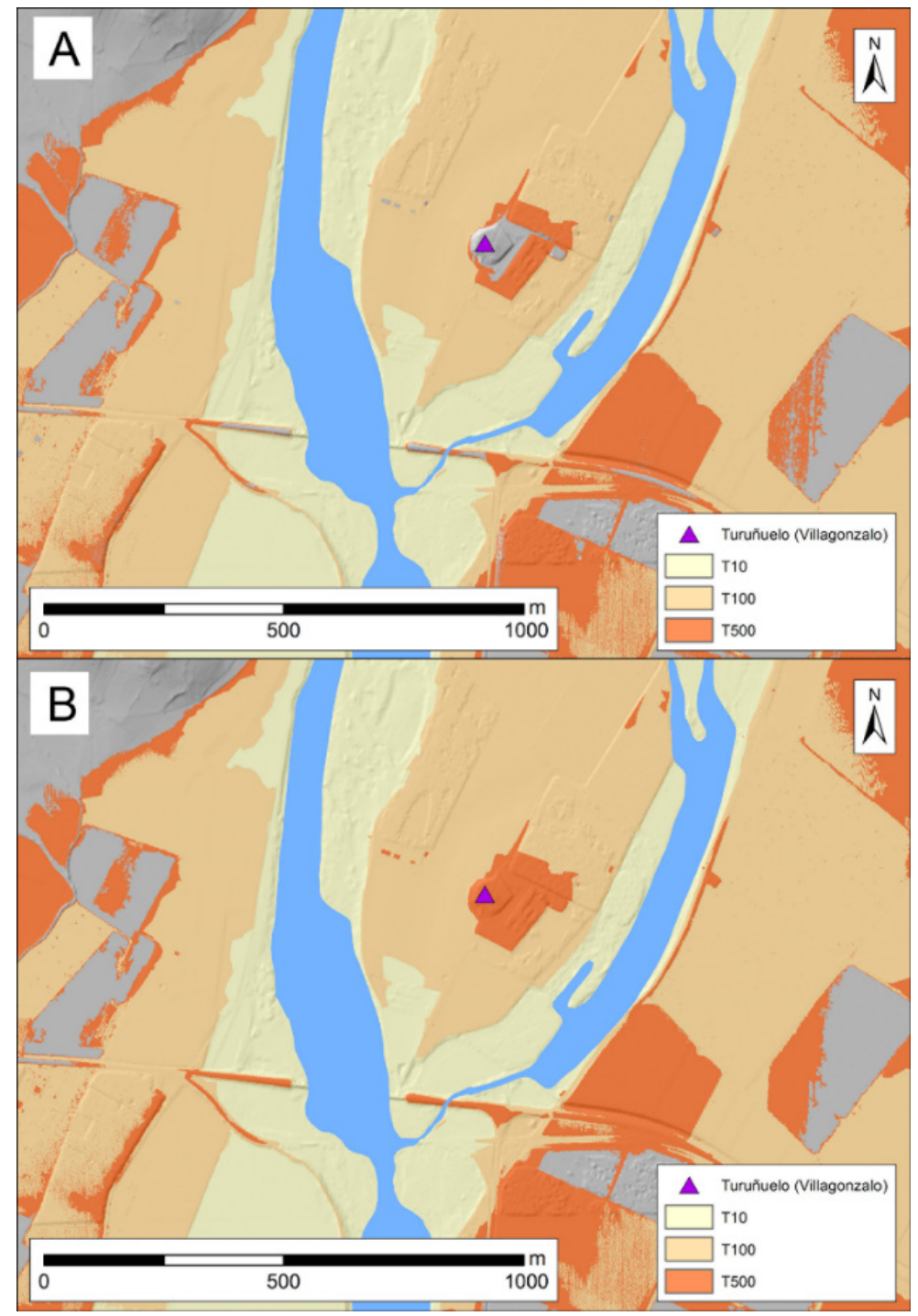

Figure 8. APSFR analysis corresponding to the territory where the Turunuelo tumulus is located (Villagonzalo, Badajoz, Spain). (A) Calculation of APSFR zones prior to the reclassification of the land. (B) Representation of the territory affected by the APSFR zones after reclassification of the terrain and correction of the distortions.

The resolution and correction of these distortions is fundamental in a project of this kind, as it allows us to prove the existence of situations in which the flood events directly 
affected the settlement, causing it to be partly or completely flooded. As we can see below, in the case of the middle Guadiana basin during the first Iron Age, the observation of events affecting the development of the sites has been fundamental in order to historically interpret them.

Finally, it should be noted that there is a geographical feature, caused by anthropic action, which generates a distortion in the models, but which we do not believe needs correction: the artificial terraces created during the re-division of the territory, which led to the existence of different levels within the same space or region. These anomalies in the orography of the terrain are detected by the presence of straight cuts in the models that stop the extension of the events in their tracks. Of the ten cases analysed in our study, this event is detected in only one of them, which we consider better not to correct for a very simple reason: we do not know which of the two elevations, the lower or the upper one of the terrace, was the original elevation (Figure 9).

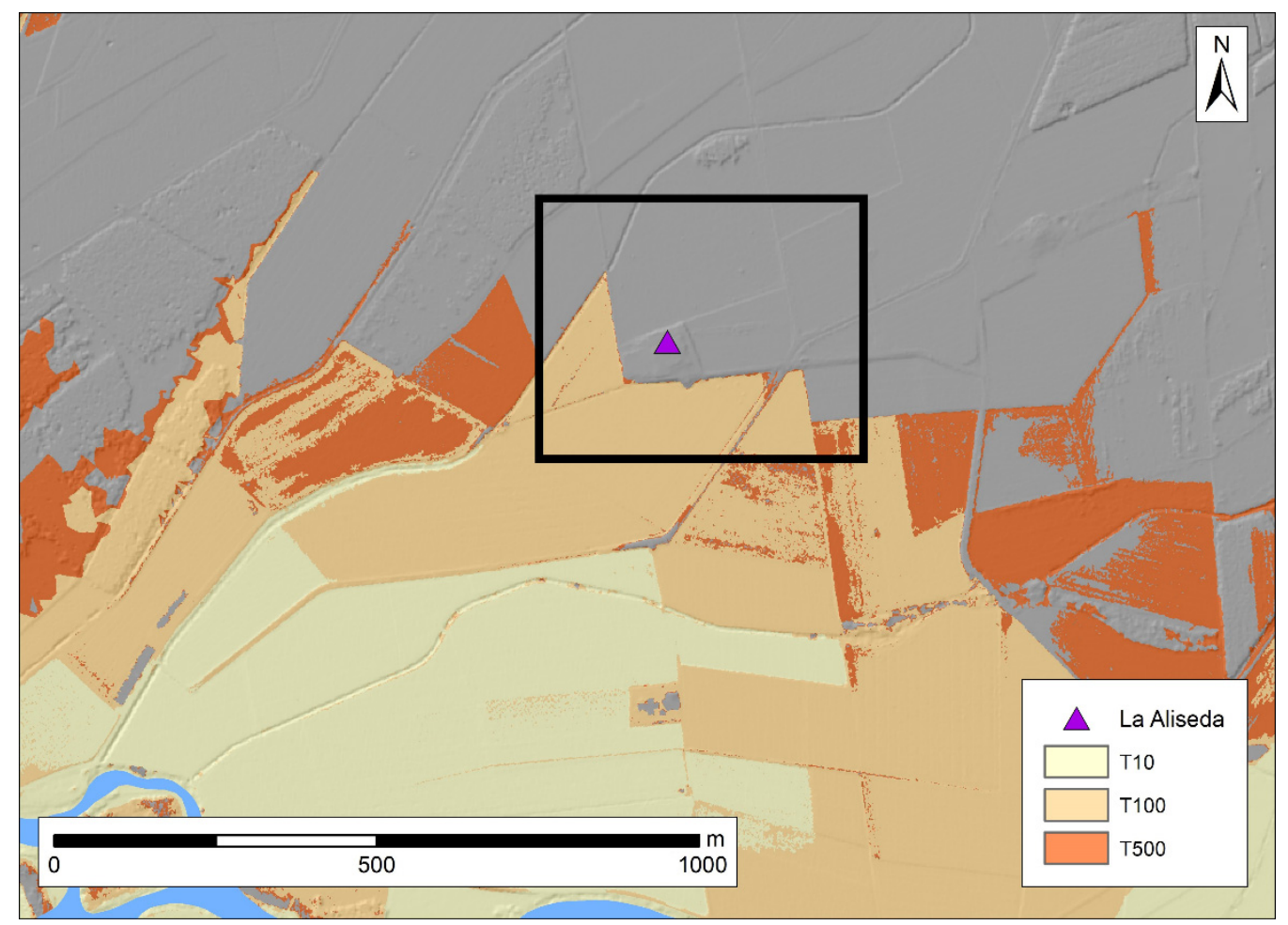

Figure 9. APSFR analysis corresponding to the area where the La Aliseda tumulus is located (Don Benito, Badajoz, Spain). It shows how both the T100 event and the T500 event stop just on the west and south faces of the mound, creating a straight distortion that marks the boundary of the plot. Therefore, the plot on which the settlement is located is at a higher elevation so that the flood event has its limits at the contour of the plot.

\section{Results}

The overall interpretation of the results allows a homogeneous interpretation to be drawn from the study, defining the clear relationship between the Guadiana settlements and the different watercourses (Table 1). In order to present the results obtained after the integration of APSFR data and reconstruction of the paleo-landscape of the middle Guadiana basin, we selected several examples in order to analyse the usefulness of the tool depending on the category of settlement to which it is applied. Given the heterogeneity of the locations of the necropolises, we selected the necropolis of El Pozo, since it is the bestknown site of its kind, and the interpretation derived from its study is highly significant. For the analysis of the village-type settlements, we selected the enclave of Cerro de la Barca-Torruco, for one main reason: it is the only enclave known to date to be located in the vicinity of the Guadiana River, since, as can be seen in Figure 1 of this paper, the 
rest of the examples are located far inland. Finally, the Tartessian buildings hidden under tumuli were analysed as a whole, given that their location in the landscape is one of the characteristics shared by these constructions, which allows us to obtain an overall assessment of the case studies.

Table 1. List of sites analysed with respect to the nearest watercourse, their height and the flood events that affect them.

\begin{tabular}{ccccc}
\hline Archaeological Site & Settlement Category & River Distance & River Height Difference & Affection Event \\
\hline Necropolis of El Pozo & Necropolis & c. $160 \mathrm{~m}$ & c. $6 \mathrm{~m}$ & T100 \\
Medellín & Flat settlement & c. $360 \mathrm{~m}$ & c. $6 \mathrm{~m}$ & - \\
Cerro de la Barca & Flat settlement & c. $130 \mathrm{~m}$ & c. $28 \mathrm{~m}$ & - \\
Huerta de Don Mateo & Tumuli & c. $365 \mathrm{~m}$ & c. $4 \mathrm{~m}$ & - \\
Casas del Cerro de la Barca & Tumuli & c. $180 \mathrm{~m}$ & c. $8 \mathrm{~m}$ & - \\
Cañada de la Virgen & Tumuli & c. $705 \mathrm{~m}$ & c. $4 \mathrm{~m}$ & T100/T500 \\
Turuñuelo (Villagonzalo) & Tumuli & c. $125 \mathrm{~m}$ & c. $3 \mathrm{~m}$ & T500 \\
Casas del Turuñuelo & Tumuli & c. $775 \mathrm{~m}$ & c. $4 \mathrm{~m}$ & T500 \\
Turuñuelo (Mérida) & Tumuli & c. 1200 & c. $8 \mathrm{~m}$ & - \\
La Aliseda & Tumuli & c. $1030 \mathrm{~m}$ & c. 8 & T500 \\
\hline
\end{tabular}

\subsection{The Necropolis of El Pozo and the Settlement of Medellin (Badajoz, Spain)}

The necropolis of El Pozo is located in the municipality of Medellín, in the province of Badajoz, on the left bank of the Guadiana, some $500 \mathrm{~m}$ to the west of the elevation where it has traditionally been assumed that the settlement was located at the same time as the necropolis (Figure 10). It was discovered in 1969, and to date, a total of five archaeological excavations have been carried out, which have documented a necropolis with three phases of occupation between the seventh and fifth centuries BC, and in which three types of burial have been identified: in urns, in a pit, in busta, or a combination of both types. [31].

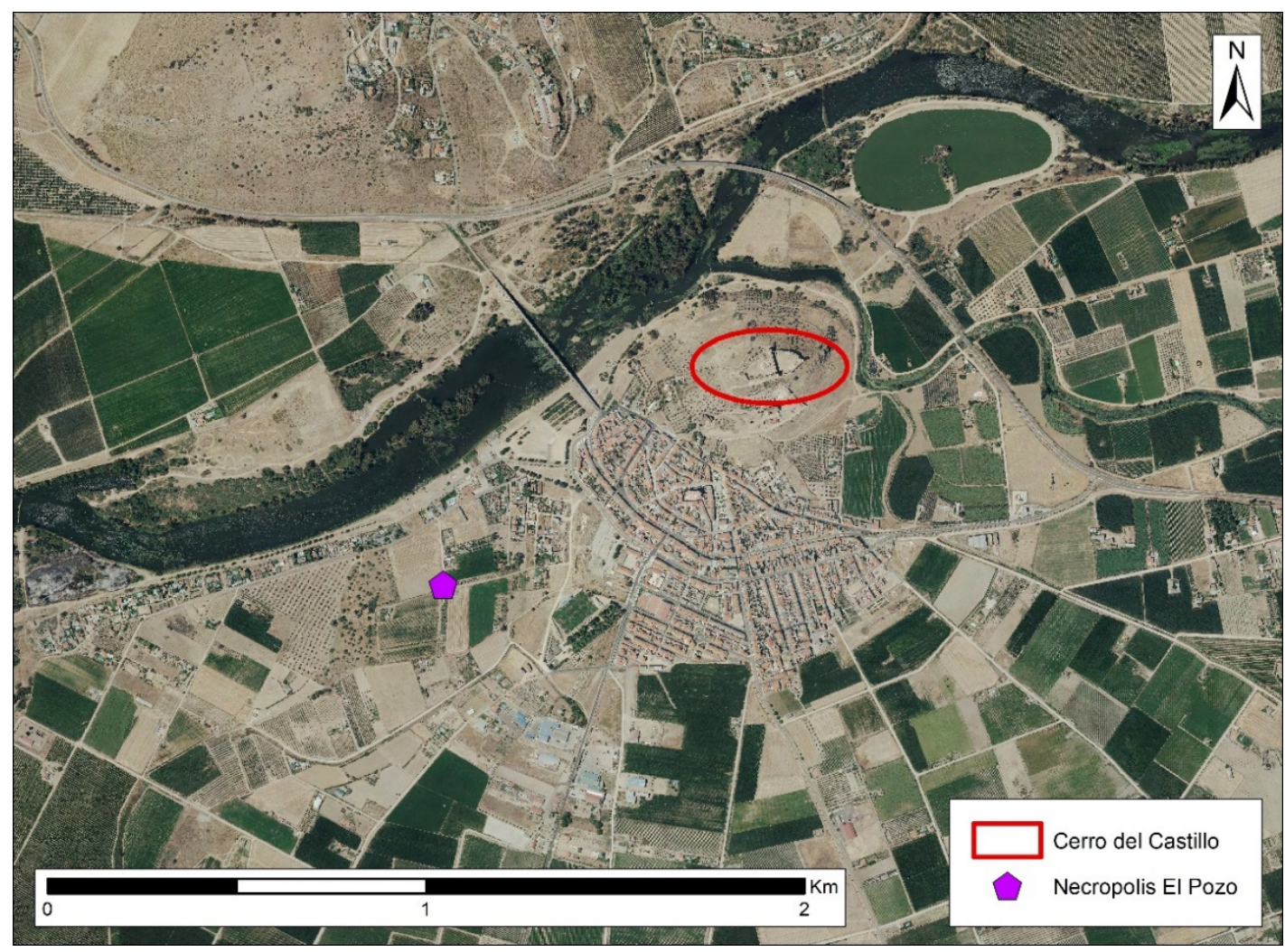

Figure 10. Location of the Cerro del Castillo and the Necropolis of El Pozo (Medellín, Badajoz, Spain). 
The combination of historical photography, LiDAR data, and APSFR has led to the reveal of results in this particular case study, making it possible to corroborate a hypothesis proposed years ago by the researchers in charge of the excavation of this burial site. Proof of this is a statement from the topographical study carried out in the 1980s, which notes that it occupies a strip of land forming a small elevation above the surrounding area, imperceptible to the naked eye, as it barely stands out 1 metre above the surrounding area. This area, approximately 1 ha in size, must have been located in antiquity between two branches that ran southwards from the current course of the Guadiana, located some $200 \mathrm{~m}$ to the north [...]. Both channels are nowadays enclosed and barely visible, as they only resurface during major floods, such as those that occurred in 1969 and 1979, which made it possible to confirm the quasi-island character of the land occupied by the necropolis, an area which, in antiquity, must have been within the riverbed flooded by the usual floods of the Guadiana river." [32] (p. 894).

However, the combination of LiDAR and APSFR data, in this case accompanied by geological mapping and historical photography, allowed us to verify the previous hypothesis and to observe that the floods of the Guadiana caused the area occupied by the necropolis to become a small island. This can be corroborated both by consulting the geological map of the Geological and Mining Institute of Spain (2008), which shows the presence of two branches of the Guadiana that run to the south of the necropolis, currently dried up, and by consulting Series A of the American Flight, where the presence of this small island can be identified, covering an area of 12-13 hectares (Figure 11).

To complete the study of the palaeolandscape of the El Pozo necropolis, we analysed its fluvial environment using APSFR data. The mapping generated shows that the space occupied by the necropolis would have been submerged in events T10 and T100. In the T10 events, the only variation detected is that the distance between the riverbed and the necropolis is reduced, while in the T100 events, the necropolis would be completely surrounded by water, suggesting that the necropolis, while in use, may have always been surrounded by water; nevertheless, this is difficult to prove.

In contrast, only event T500 would have affected the tombs, submerging the remains under the waters of the Guadiana, because although the necropolis stands on a slight elevation, its level would not be high enough to protect it from flooding (Figure 12). These floods, which occurred every 500 years, have been fossilised in the archaeological record. In the stratigraphic sequence of the necropolis, there are traces of some events. Specifically, Stratum II, $0.25 \mathrm{~m}$ thick, has been related to the flooding of the river between 1940 and 1941, while Stratum III, which is thicker, reaching up to 2 metres in some points and covering the entire area of the necropolis, would be the result of various periods of flooding [33]. Today, this process still occurs, with the last event documented in the 2013 floods.

The process documented in the necropolis of El Pozo is not an isolated event, but is repeated in other case studies documented in the middle Guadiana around its Iron Age necropolises. This is the case for sites such as the necropolis of Valdelagrulla (Medellín, Badajoz, Spain) or Aljucén (Mérida, Badajoz, Spain), where the application of APSFR data corroborated the existence of watercourses that surrounded these funerary spaces in ancient times.

Before concluding the presentation of the results of the study of the palaeolandscape of the necropolis of El Pozo, we would like to highlight an aspect revealed by an analysis of the topography of its surroundings, in relation to a decades-long debate on the location of the settlement associated with this necropolis. Traditionally, an area of scientific research defended the presence of a protohistoric settlement in Medellín, contemporary to the necropolis, which would have been located on the nearest elevation, the hill of Medellín Castle [34]. A review of the 21 interventions carried out on this elevation revealed that there are no occupation levels that allow us to confirm that this elevation was inhabited during the first Iron Age [3], leading us to consider that it was occupied in the Chalcolithic period [35] and Roman period [36]. 


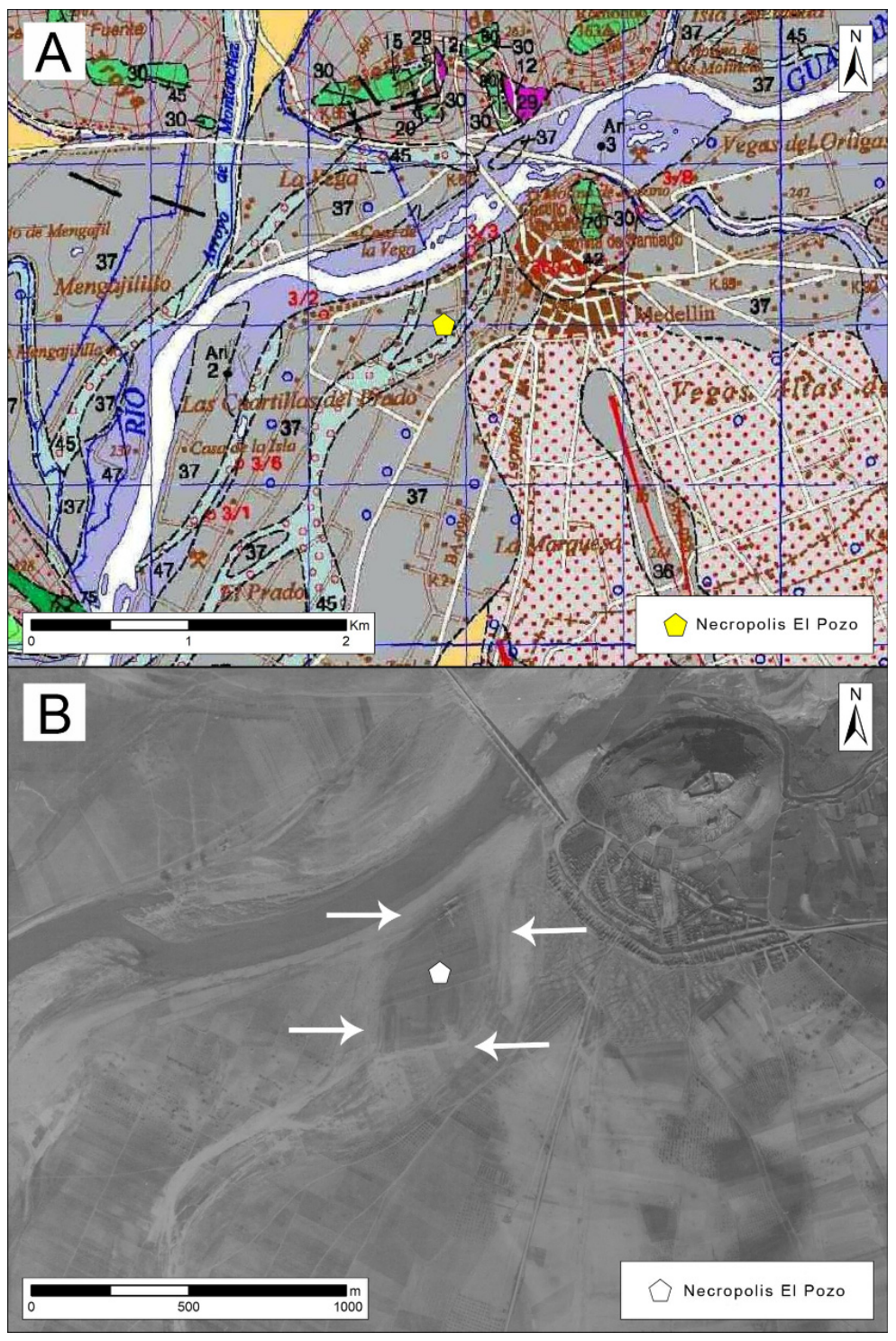

Figure 11. (A) National geological map (IGME, sheet 778) showing the location of the necropolis of El Pozo. It shows the presence of a branch of the Guadiana running to the south of the necropolis, which no longer exists. (B) Photograph of American Flight A (1945/1946) showing the location of the necropolis of El Pozo. The white arrows show the traces of the paleochannels of the Guadiana, which have now dried up.

In contrast to this proposal, previous studies have alluded to evidence that locates the protohistoric settlement of Medellín beneath the current town, at the foot of the southern slope of the hill [2,3] (p. 106) (Figure 13). This hypothesis gains strength after applying our spatial analysis methodology combining LiDAR and APSFR data. Interestingly, the proposed location of the settlement is the only point that is safe from flood events. At the same time as the settlement was protected from the floods, it took advantage of the fertile lands of the river plain. Thanks to the insight provided by this working methodology, we can now reaffirm our hypothesis about the location that the settlement of Medellín must have occupied during the first Iron Age, while waiting for the archaeological studies of the projects carried out in the area to confirm it. 


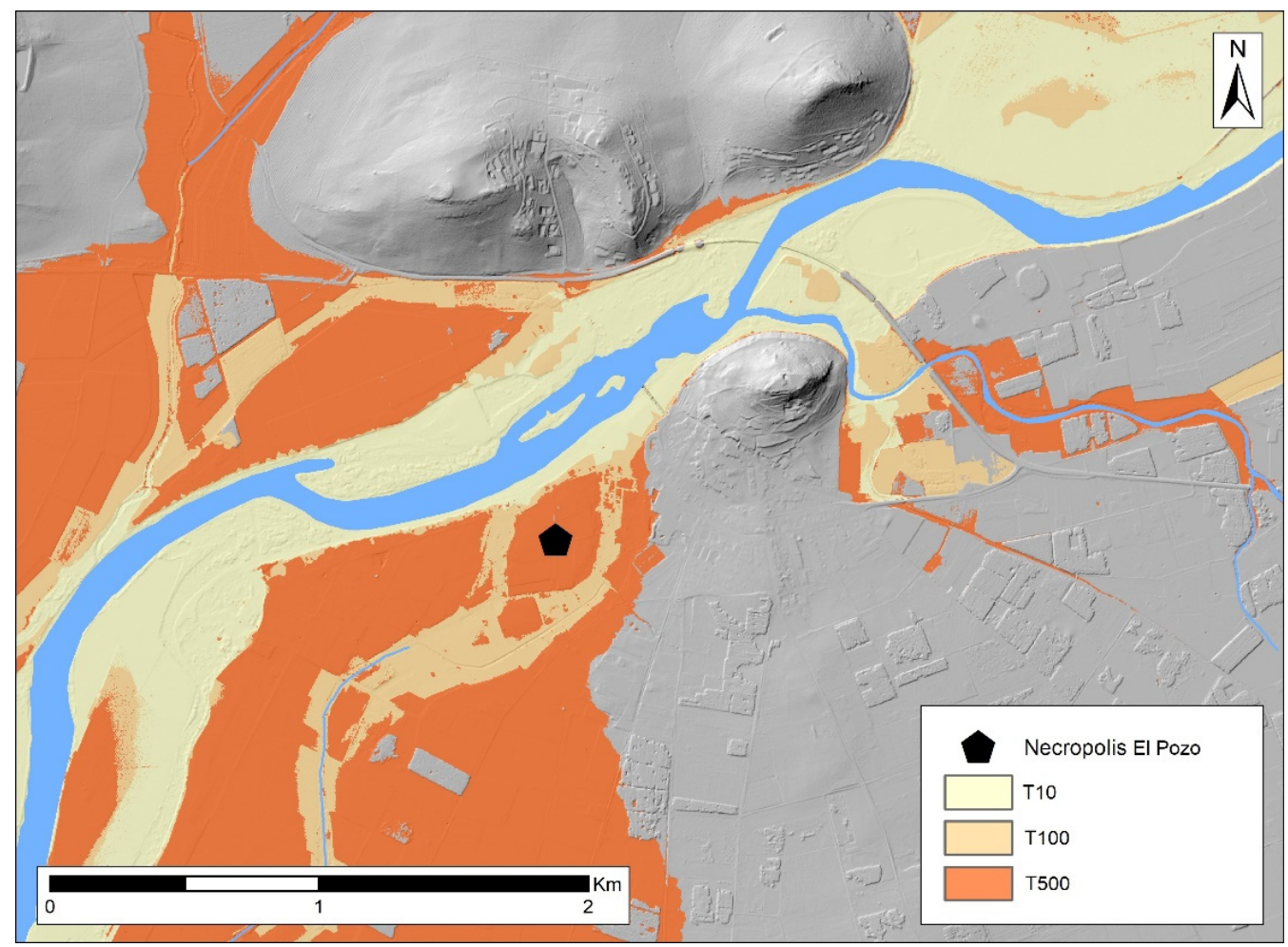

Figure 12. APSFR analysis corresponding to the territory where the necropolis of El Pozo (Medellín, Badajoz) is located. It shows how the necropolis was affected by event T500.

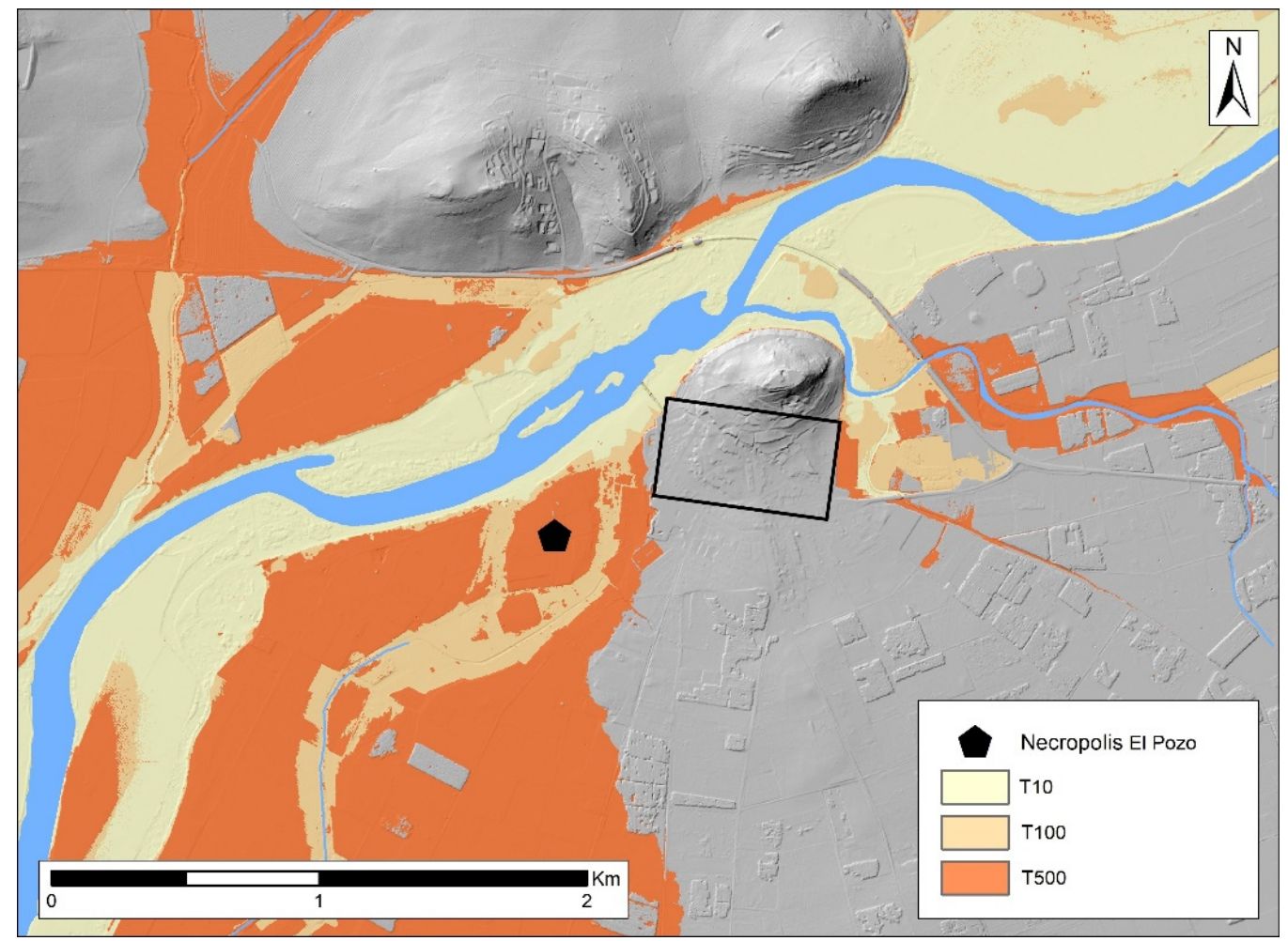

Figure 13. Cartography showing the hypothetical location of the first Iron Age settlement of Medellín, marked with a black rectangle (Badajoz, Spain). 


\subsection{The Village Type Settlement of Cerro de la Barca-Torruco (Villanueva de la Serena, Badajoz, Spain)}

The site of Cerro de la Barca-Torruco is located in the municipality of Villanueva de la Serena, on a low hill overlooking the Guadiana River, on its right bank [37]. Its location in the landscape, given that it is a small village on a plain, differs markedly from the previous case study, so that the results present us with a very different situation.

Despite the fact that this site has never been excavated, its occupation is well defined and delimited both by the presence of abundant archaeological material, which allows for its functional and chronological characterisation, and by the presence of documented remains of structures on the current surface. As far as the dimensions of the enclave are concerned, the survey work allowed us to define a settlement with an approximate surface area of 3 hectares [3] (p. 137). The chronology of the was also determined thanks to the discovery of a bronze plaque with zoomorphic decoration, whose closest parallels have been documented at the site of Cancho Roano (Zalamea de la Serena, Badajoz, Spain). This piece and the presence of type CR-1B amphorae allow us to date the site to between the sixth and fifth centuries BC.

The distance between the Cerro de la Barca-Torruco site and the Guadiana River is very close, as the site is currently located $130 \mathrm{~m}$ from the riverbank. This led us to consider the possible effect that the river floods could have on the site. The combination of LiDAR and APSFR data allowed us to verify that none of the documented flood events would have affected the site, as it is located at a high enough point to protect it from these events. We can see how the layout of the riverbank at this point has not changed over the years, with the northern end, i.e., the fields or plots located beyond the opposite bank, usually being affected by the increased flow of the river, given that it is in this area where the river's flood plain is located. The photograph of American Flight B (1956-1957) reveals the presence of several branches of the Guadiana located to the north of the site, which are currently dried out (Figure 14). The presence of both watercourses means that the space between them falls within the area affected by events T10, T100 and T500 (Figure 15). In the past, the regular flooding of the land to the north of the site meant control over fertile stretches of plain that would have favoured the development of agriculture. The position occupied by the enclave, on the slope of the hill overlooking the river, would have allowed it to control both the fertile lands in front of it and the course of the river, whose role as a fundamental artery for the connection between the different enclaves located in the surroundings of its course within the middle section of the River Guadiana is becoming increasingly clearer.

\subsection{Tartessian Buildings Hidden under Tumuli in the Middle Guadiana Basin}

At present, the archaeological work carried out in the middle basin of the Guadiana allowed us to discover a total of 13 tumuli [3] (p. 164). Only three of them have been excavated to date; however, all the information recovered from these interventions provided us with extensive knowledge of the architectural and physical characteristics of these buildings. Cancho Roano (Zalamea de la Serena, Badajoz, Spain) [38] and La Mata (Campanario, Badajoz, Spain) [39] have already been fully excavated, while the structure of Casas del Turuñuelo (Guareña, Badajoz, Spain) [40] is currently in the process of being excavated and studied.

As we noted in the introduction to this paper, what we refer to as Tartessian buildings hidden under tumuli are a characteristic system of settlements exclusive to this region during the Iron Age. Their closest parallels are to be found in the Guadalquivir valley, the heartland of Tartessus. They share architectural and material characteristics with these buildings, although the particular feature that makes the Guadiana buildings different from their neighbours in the area of the Guadalquivir is their spatial distribution and the system of destruction and abandonment they suffered at the end of the fifth century BC. The buildings of the middle Guadiana basin were intentionally sealed, destroyed, set on fire, and then covered with earth to effectively conceal them under an artificial mound that protected them from the passage of time. This method of concealment helped to 
preserve both the constructive remains and the materials, allowing us to discover aspects of Tartessian culture that were hitherto unknown.

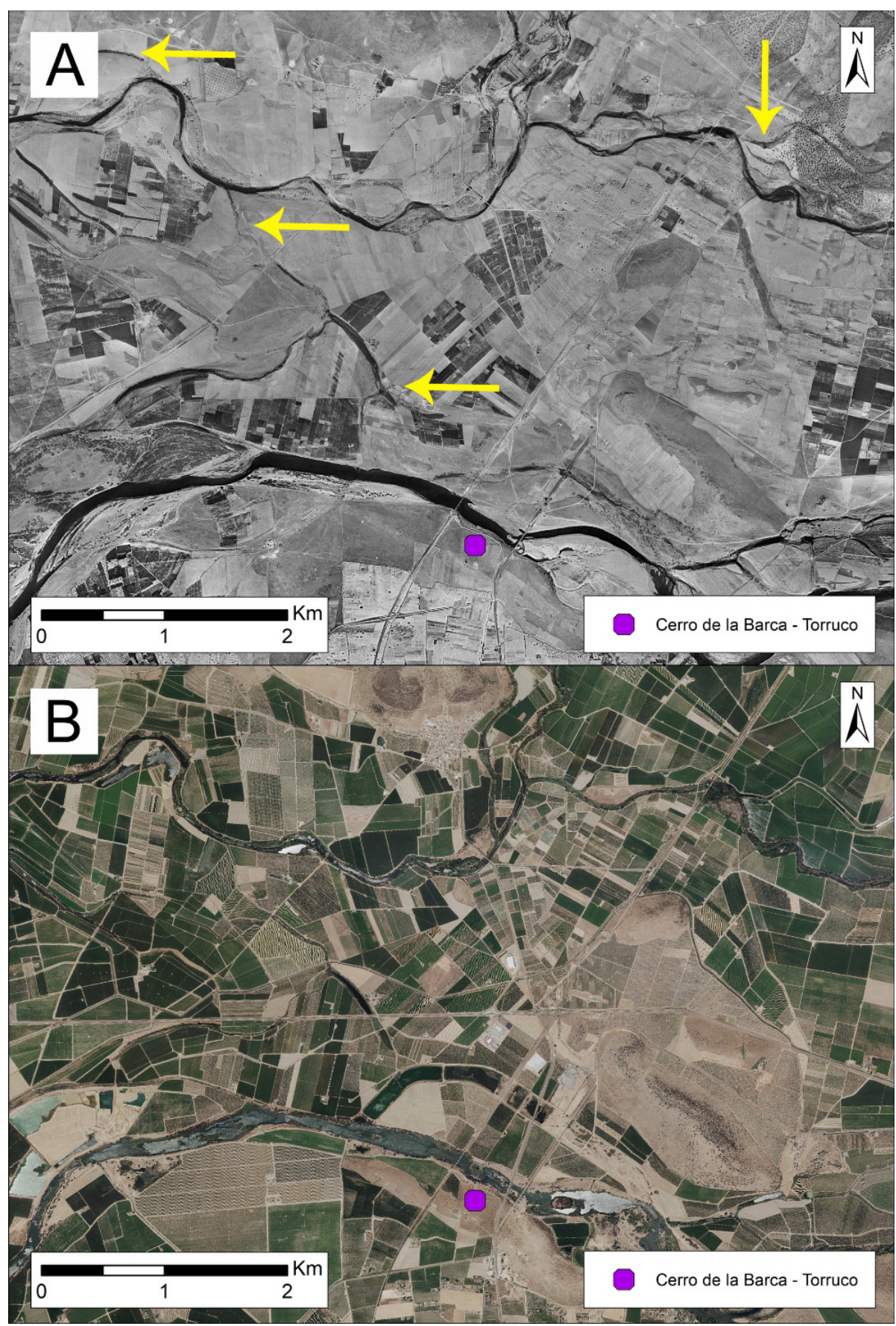

Figure 14. Comparison between the orthophotographs of the American Flight B, made between 1956/1957 (A) and the PNOA Máxima Actualidad (B) of the territory that extends to the north of the village of Cerro de la Barca (Villanueva de la Serena, Badajoz, Spain). It shows how some branches of the Guadiana have dried out. 


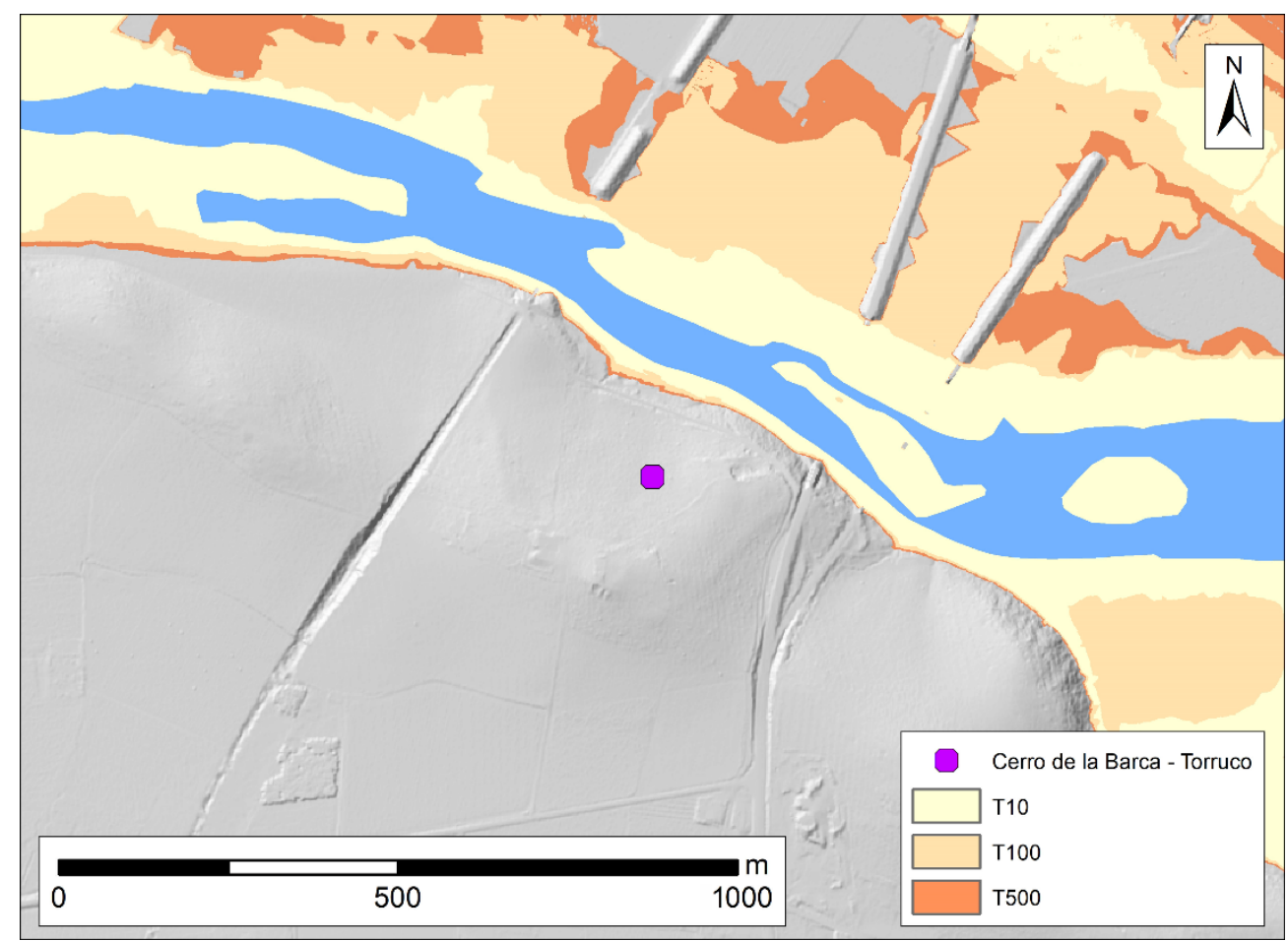

Figure 15. APSFR analysis corresponding to the territory in which the settlement of Cerro de la Barca-Torruco (Villanueva de la Serena, Badajoz, Spain) is located. It shows that none of the recorded events affect the site.

The proximity of these constructions to the Guadiana River is one of the characteristics shared by the Tartessian buildings of the Guadiana. All except four are located at the confluence of the river with one of its main tributaries (Figure 16). This position gave the buildings a strategic position that allowed them to dominate extensive areas of land, including fertile plains for the development of agriculture; at the same time, they controlled one of the main means of communication in this territory: the rivers. In previous works, we defended the importance of the Guadiana as the backbone of the territory on which the main trade of this region would have been based [2] (p. 256). This hypothesis has been supported by the appearance of the first images of boats found at the site of Casas del Turuñuelo [41], as well as in the analysis of the amphorae documented in each of the excavated sites. The analysis of the clays made it possible to verify the existence of small-scale commerce that connected these sites along the Guadiana [42].

The prominent role these buildings played in the political and territorial organisation of this area was not only due to their location in the landscape, but also to their architectural and material wealth. Alongside the monumental architecture, there are also groups of Mediterranean imports that emphasise the important political role that these enclaves played in this area between the sixth and fifth centuries BC [3].

Of the total number of documented tomb elevations in the Middle Guadiana, we managed to examine a total of nine using the APSFR methodology proposed in this paper: Cancho Roano, La Mata, Las Lomas and Lácara, as they are four enclaves located in the interior of the Guadiana, next to one of its tributaries, but far from the main artery of the Guadiana. As we do not have predictive models to evaluate the areas with potential flood risk in the cases corresponding to the tributaries of the Guadiana, we do not have sufficient information to evaluate the spatial relationship between them and their nearby watercourses. 


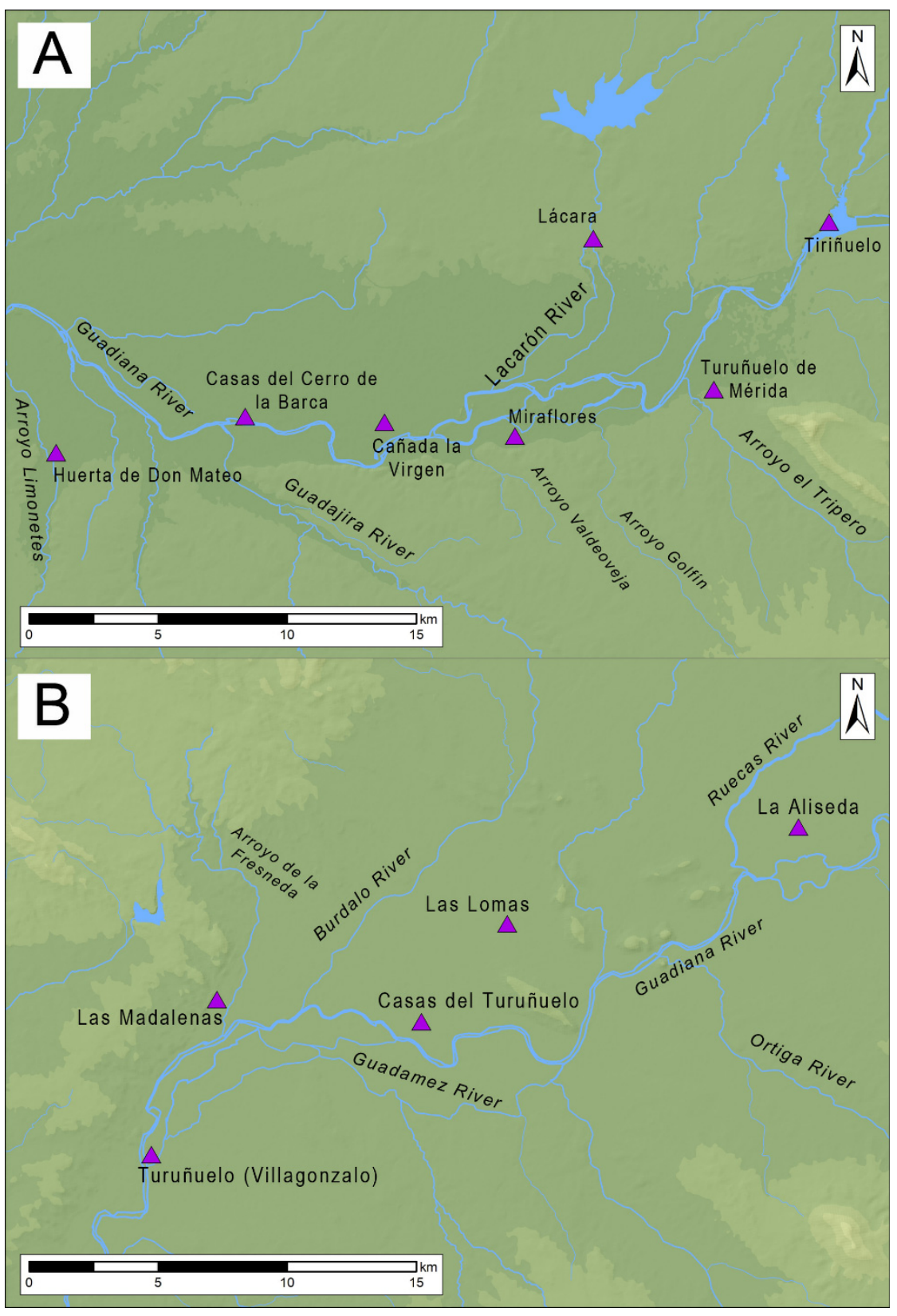

Figure 16. Maps (A,B) showing the location of the Tartessian buildings hidden under tumuli in relation to watercourses. The layout of these constructions always places them next to a watercourse, mainly along the Guadiana, the main communication artery of this territory.

The application of the APSFR data to the DTMs generated after the processing of the LiDAR flights allowed us to make some very interesting observations. First of all, it should be noted that all the elevations are safe from the events that occur every 10 years. This is quite logical, because if we take into account that the approximate lifespan of these buildings is about 100 years on average, preventing the floods that occur every 10 years from affecting the buildings, as well as the surrounding constructions where the production areas would be located, is something that is quite controllable. All the examples under study are located outside the T10 events, while still being located close to the land affected by these floods, allowing the buildings to control areas of fertile land for agricultural development (Figure 17). 


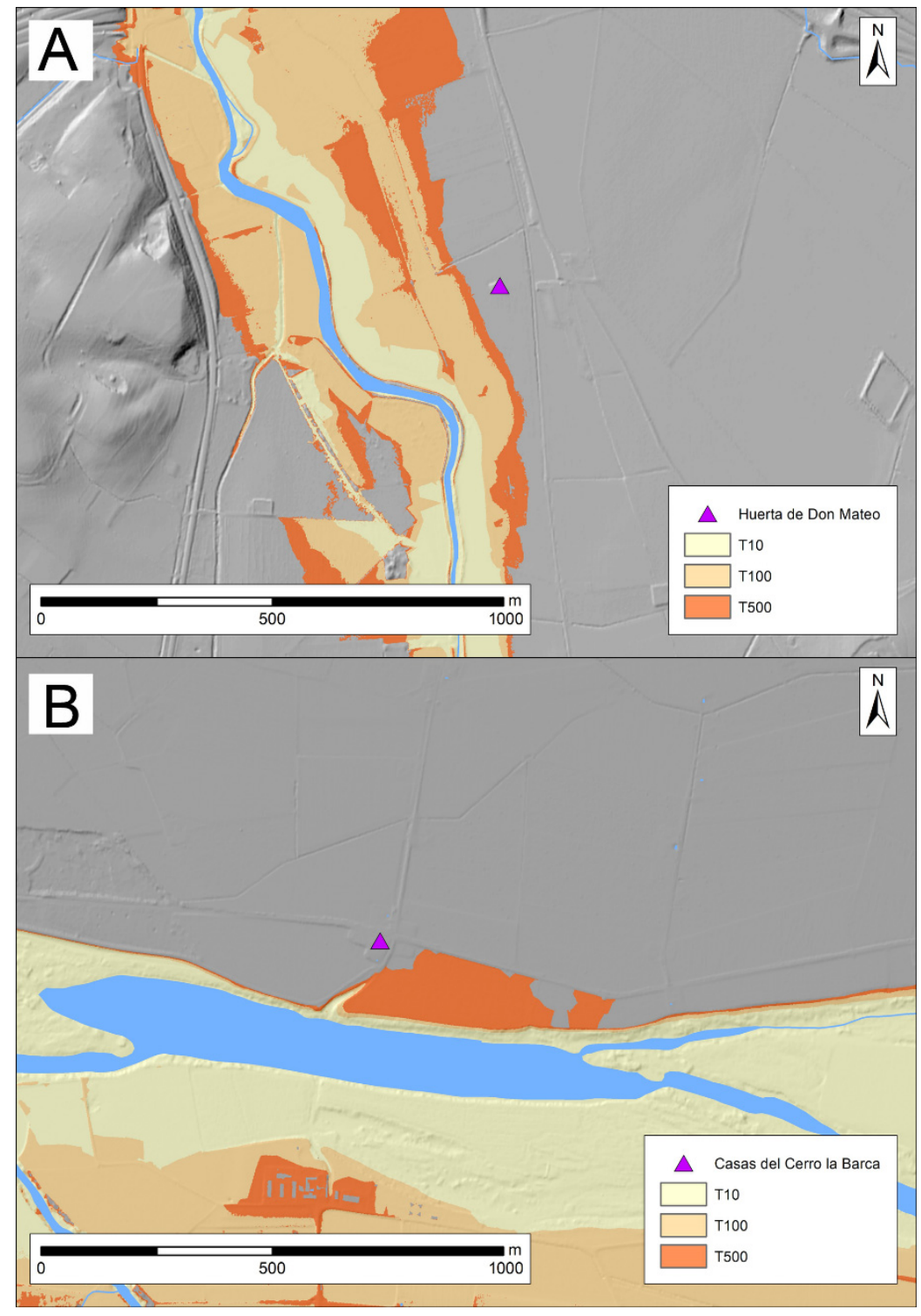

Figure 17. Models obtained from the APSFR analysis of the tumuli of Huerta de Don Mateo (Talavera la Real, Badajoz, Spain) (A) and Casas del Cerro de la Barca (Badajoz, Spain) (B) showing the location of the buildings with respect to the three flood events.

Only one of the examples seems to have been affected by the T100 event. This is the tumulus of Cañada la Virgen (Puebla de la Calzada, Badajoz, Spain) (Figure 18), one of the enclaves most affected by modern-day agriculture, as due to the Badajoz Plan, this site has been completely razed, which is why the results obtained in this analysis have raised some doubts, given the alteration that both the site and its surroundings have suffered. In contrast, there are several examples which are either not affected by any of the events, or which are only affected by T500 events, which, given the lifespan of these buildings, could not possibly be controllable or predictable. We can point out examples such as the tumuli of Turuñuelo de Villagonzalo or Casas del Turuñuelo, which would have been submerged under the waters of the Guadiana in events occurring every 500 years (Figure 19). 


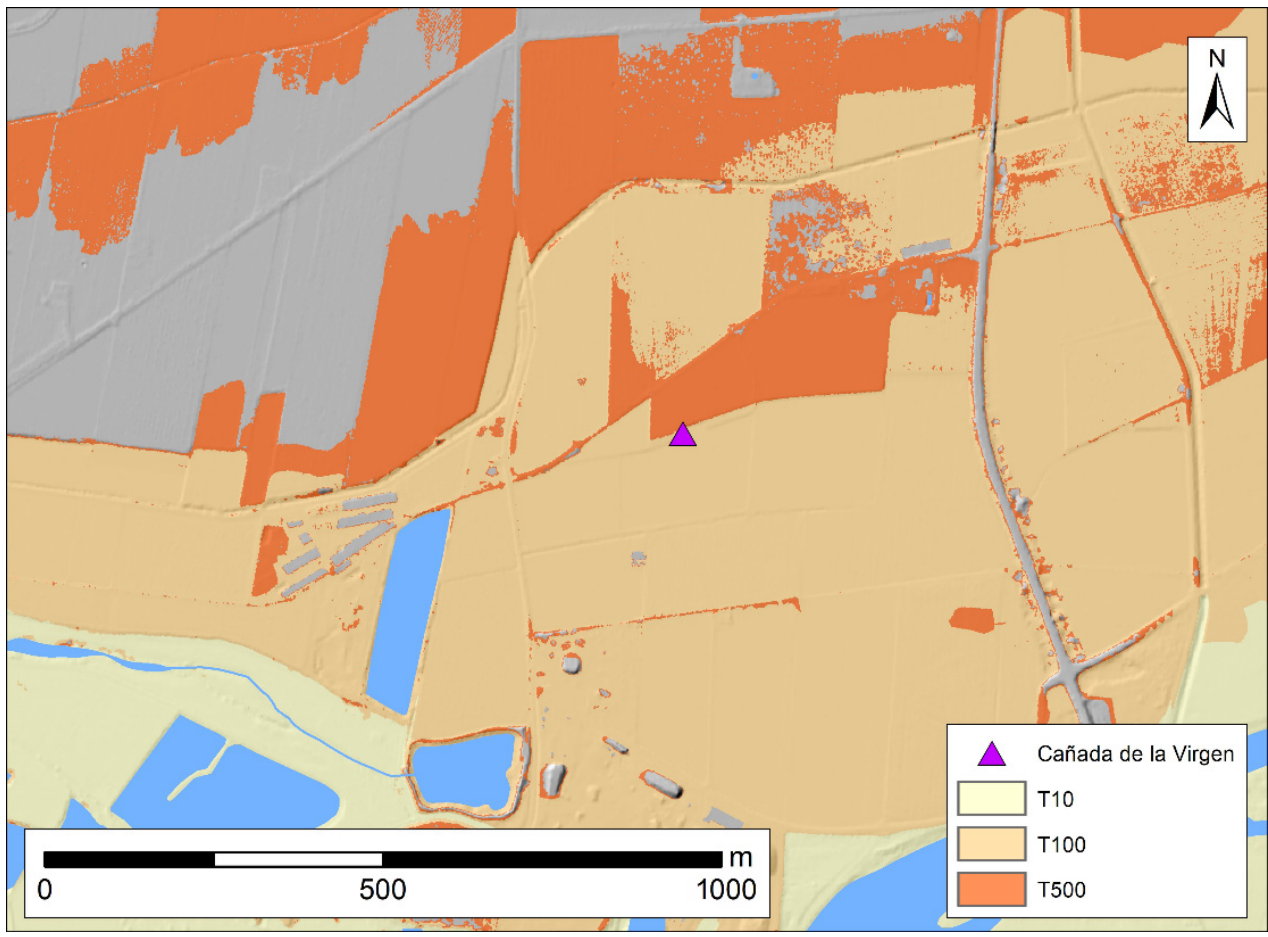

Figure 18. Model obtained from the APSFR analysis of the area where the tumulus of Cañada la Virgen (Puebla de la Calzada, Badajoz, Spain) is located, showing the effect of events T100 and T500 on the site.

At the Villagonzalo site, no archaeological work has been carried out to date to verify the existence of stratigraphic units that can be identified with flooding events. However, the work at the tumulus of Casas del Turuñuelo has provided evidence that it has been affected by flooding events that have lasted for a considerable period of time. Evidence of this has been found in the southern profile of the tumulus, where a sequence of sediment deposits made by the river in the years following the concealment of the building has been documented, and in the sequence of the courtyard, where there is evidence of a flooding level beneath the ritual deposit of animals that is currently being analysed using micromorphology, to determine its chronology and scale. The fact that we now have evidence that allows us to assess the effect that the river itself may have had on these constructions leads us to begin a new line of work on the causes that led to these structures being abandoned and sealed. 


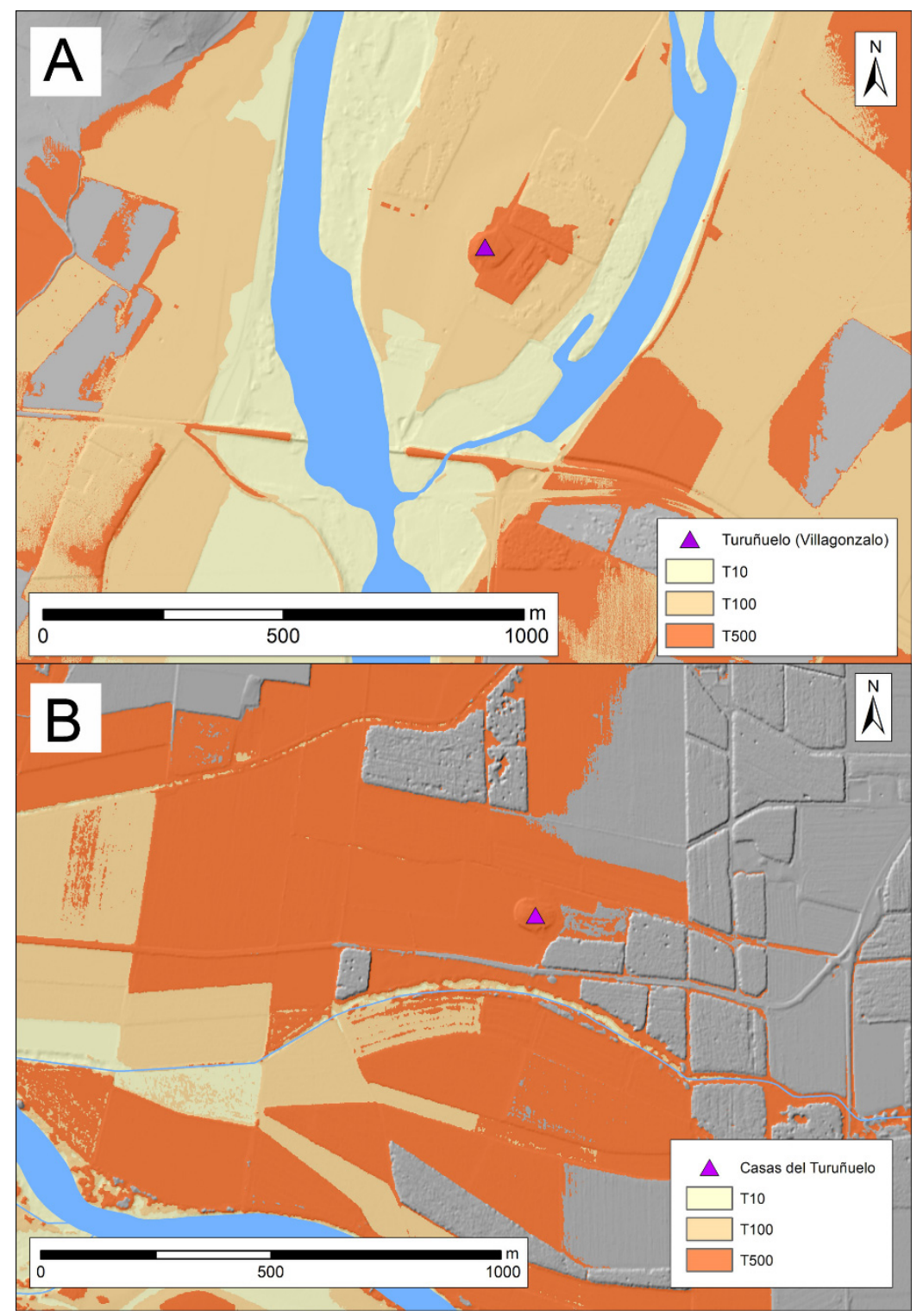

Figure 19. Models obtained from the APSFR analysis of the tumuli of El Turuñuelo (Villagonzalo, Badajoz, Spain) (A) and Casas del Turuñuelo (Guareña, Badajoz, Spain) (B) showing how the T500 event affected both the buildings and their surrounding land.

\section{Discussion}

The historical analysis of the landscape in regions such as the middle Guadiana basin, which has been greatly altered by the impact of agricultural work, has always entailed great difficulties. The orography and landscape of these territories is so seriously affected that reconstructing their original morphology is, in many cases, an impossible task. The transfer of land, the redistribution of plots and, above all, the levelling to which many of these fields have been subjected, has led to the loss of valuable archaeological information, especially that which corresponds to the so-called peasant settlements, since, in contrast to the Tartessian buildings hidden under tumuli, the scarcity of their material and architectural remains means that the archaeological footprint they leave on the territory is very small and easily destroyed.

In response to this, through archaeology and landscape analysis, we seek tools that will help us to restore a territory to its original appearance, the structure it would have had prior to the impact that agriculture has had on its configuration, and on the conservation of the sites in its surroundings. This is the case of the methodology used in the present 
study, through which we intend to identify the activity that the Guadiana River has had throughout its history and how this activity has affected the sites located in its immediate surroundings, to the point of conditioning the development of its activities or determining the moment of abandonment of the sites.

To do so, we used historical photography and LiDAR to identify the presence of paleochannels or old branches of the Guadiana that were in operation in the past, possibly prior to the regulation process that affected the river due to the construction of the reservoirs. However, this analysis of the river network does not allow us to address the relationship between the river and its settlements. For this reason, we have searched for a tool to help us simulate flood patterns. In this way, overcoming contemporary obstacles such as the tomb elevations, the terraces or the plots sown with maize, we can determine how the settlements were affected by the flooding of the Guadiana in events occurring every 10 , 100 or 500 years.

In light of the results obtained, we can confirm the usefulness of the methodological proposal contained in this work. Thanks to it, and despite the fact that it is not an absolute model, and that within it and depending on each geographical region, different variables must be taken into account, we have managed to configure the most realistic possible image of the structure that the middle Guadiana basin would have had in antiquity, using this as the basis to analyse the relationship between the river, the areas for exploiting resources, and the different settlements.

Perhaps the first idea to be drawn from this study is the importance of reconstructing the palaeolandscape, as analysing the location of sites using the current landscape as a reference point can result in a number of errors. This is especially the case in regions such as the middle Guadiana basin, where the human impact on the territory is so significant that many of the sites under study have lost their connection or relationship with the territory. For this reason, it is necessary to define the original route of the river or to identify river arteries that are currently silted up, which in ancient times must have played a fundamental role in the organisation of the territory and in the choice of areas for building settlements.

Leaving aside the territory in which the necropolises are located, the application of this methodology has made it possible to corroborate the relationship that existed between the settlements of the first Iron Age and the Guadiana River. The position occupied by both the settlements on the plains of the village or farm type, and the Tartessian buildings hidden under tumuli in the territory, close to the watercourses and, mainly, to the areas affected by the flooding of the rivers, allows us to consider the fundamental role that the waterways played in the political and economic organisation of the territory. In addition to controlling the passage of one of the main communication arteries, the Guadiana, the proximity to the lands affected by the floods made it possible to control the most fertile plots, those that were periodically affected by the floods, which led to an increase in the productivity of the land. This model is by no means exclusive to this territory and is widely attested in other parts of the Mediterranean.

The analysis of the resulting cartography allows us to observe how all the sites documented to date are outside of the T10 events, which reveals the knowledge that the societies that inhabited this area between the seventh and fifth centuries BC had of their surroundings. Given that these are events that occur every ten years, control over them would have been more effective. This would allow the sites to be located at a sufficient distance to prevent the floods from affecting the buildings, while at the same time leaving the fertile land near the riverbed under their control. In this way, the height/width represented in the T10 events can be interpreted as the space within which the course of the river would have been located during antiquity, prior to the regularisation of its course; in other words, the shading that the T10 event occupies in the models corresponds to the zone through which the course of the river may have potentially run, differing from the current one. This idea does not mean that in the past, the river occupied the entire width that the T10 shading shows in the models, but rather that this width defines the maximum limits that the river would have reached and the space through which its course was 
diverted. This can be corroborated by superimposing the T10 event layer on the historical photograph prior to the construction of the reservoirs and the current orthophotography, where the narrowing of the river can be detected. To illustrate this idea, we selected one stretch of the river between the towns of Medellín and Don Benito/Villanueva de la Serena (Badajoz, Spain), as it contains a large number of sites (Figure 20).

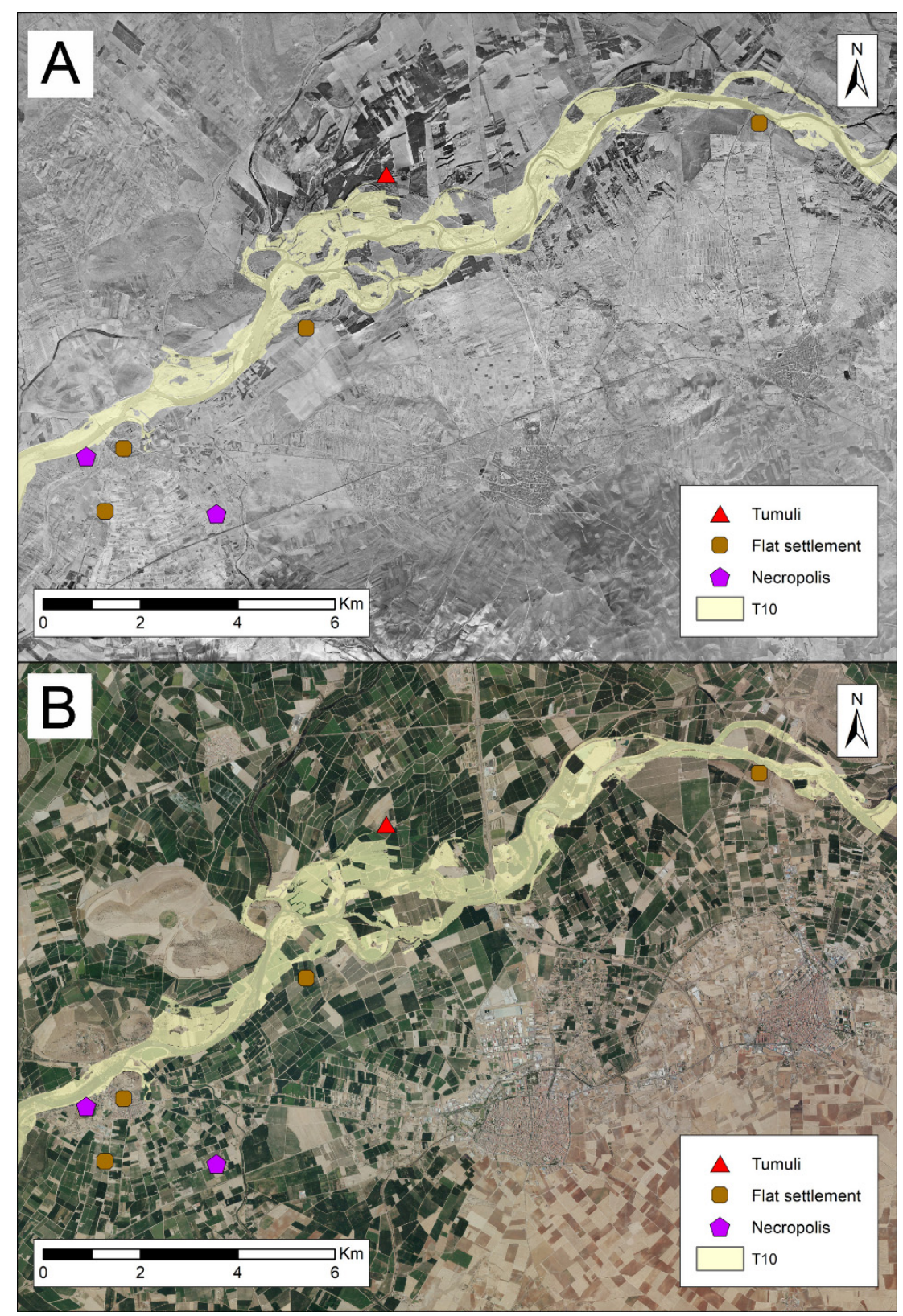

Figure 20. Cartography resulting from superimposing the T10 shading on a photogram of the AMS (B) (1956-1957) (A) and a photogram of the most recent PNOA (B) to observe the impact that the execution of the Badajoz Plan had on the course of the river.

The knowledge possessed by the societies that inhabited this area in antiquity about the events that occurred every 10 years also seems to be in relation to the T100 events, as we only have one case study, the tumulus of Cañada la Virgen (Puebla de la Calzada, Badajoz, Spain), affected by this event.

In contrast, the degree of impact exerted by events occurring every 500 years is much greater, which has allowed us to draw up a set of hypotheses. Given the chronological extent of these events, which occurred every 500 years, it is coherent to think that the 
inhabitants of the different enclaves or settlements were not able to predict the arrival of these events or floods. If we refer to the chronologies in which the sites of the first Iron Age are active in the middle Guadiana basin, it is true that, with the exception of Cancho Roano, which has several phases of occupation, it seems that the rest of the enclaves were only in use between the sixth and fifth centuries BC, so that their activity does not seem to exceed two centuries. Therefore, predicting or avoiding flood damage every 500 years would not have been easy.

\section{Conclusions}

By applying this methodological model to a specific territory, such as the middle Guadiana basin, and to a specific chronology, the first Iron Age (seventh to fifth century BC), a series of historical conclusions can be drawn that help us to interpret the settlement of this region during its protohistory. This is the ultimate goal of our work: to extrapolate spatial data to a historical reality in order to assess how the physical environment has conditioned the development of human activity.

Given that the study carried out concerns various categories of settlement, there are several interpretations that can be drawn from this study. Nevertheless, it is true that the sample we have available to analyse the location of village or farm settlements is too small to draw general conclusions; however, the location of the Cerro de la Barca-Torruco site reveals the interest in these enclaves regarding their location near watercourses with the aim of exploiting the fertile land left in their wake, as well as in using them as communication routes for the transport of goods.

As far as the necropolises are concerned, the application of APSFR data has allowed us to confirm the relationship between watercourses and the location of these funerary spaces [43]. The analysis of all the known cases has confirmed the presence of a watercourse that separates the necropolis from the settlement with which it would have been connected. This evidence is not exclusive to the middle Guadiana, but dates back in time to the Phoenician necropolises both in the east and west [44], and is also present in the Tartessian necropolises of the Guadalquivir valley [45]. Detecting this pattern in the Guadiana basin confirms the survival of a tradition, the roots of which go back to the arrival of eastern populations in the Iberian Peninsula.

However, undoubtedly the most significant data are derived from the spatial analysis of the territory occupied by the Tartessian buildings hidden under tumuli. In this sense, one of the debates still pending in the research on this type of settlement refers to why these structures were suddenly abandoned and concealed at the end of the fifth century $\mathrm{BC}$. This was an event that occurred at the same time as all the constructions, resulting in a massive abandonment of this area, the middle Guadiana basin, which remained practically uninhabited until the arrival of the Romans. Traditional literature has sought an explanation for this exodus in the arrival of populations from the north, specifically of Celtic origin [46]. However, archaeology shows that the sealing and concealment of these structures would have taken days of work and required the help or collaboration of a large part of the surrounding population. It is therefore inconceivable that under the pressure of a siege or conquest, such a task could be carried out. It should also be remembered that in examples such as Cancho Roano or Casas del Turuñuelo, the sealing of the buildings was accompanied by a ritual that included a mass sacrifice of animals, which requires even more time to be carried out; a ritual that fits perfectly with the occurrence of an environmental catastrophe. It is also striking that remains of weapons, or evidence of looting or violence were found in none of the contexts analysed, which undermines the hypothesis of pressure from populations from the Meseta.

For some time, we have considered the possibility that a change in climate, possibly in the rainfall pattern, caused these settlements to be abandoned, and their populations to move to other parts of the Iberian Peninsula. However, the application of this APSFR methodology has allowed us to add another cause or hypothesis that we will have to corroborate with the help of disciplines such as microstratigraphy and carpology. This 
refers to the possible effect that the T500 event had on these structures, corroborated in examples such as the site of Casas del Turuñuelo, in whose lower courtyard the remains of a flood have been documented, over which animals were sacrificed prior to the building being sealed [47].

As the life span of these structures was around a century between the sixth and fifth centuries BC, we can assume that the societies who occupied these buildings were able to predict events occurring every 10 to 100 years, but not to calculate events occurring every 500 years. This leads us to suppose that one of these events caused the collapse of the territorial system, forcing these populations to abandon their buildings and move to other parts of the Iberian Peninsula, putting an end to the territorial model of this region during the first Iron Age. The power that these constructions held and their symbolic importance led their inhabitants to conceal them and protect them from looting or destruction, allowing many of them-those unaffected by agricultural work - to reach us in an excellent state of preservation.

Author Contributions: Conceptualization, E.R.G., P.P.D. and S.C.P.; methodology, E.R.G. and P.P.D.; software, P.P.D.; validation, E.R.G. and P.P.D.; formal analysis, P.P.D.; investigation, E.R.G. and S.C.P.; resources, E.R.G., P.P.D. and S.C.P.; data curation, E.R.G. and P.P.D.; writing—original draft preparation, E.R.G.; writing-review and editing, E.R.G., P.P.D. and S.C.P.; visualization, E.R.G. and P.P.D.; supervision, S.C.P.; project administration, S.C.P.; funding acquisition, S.C.P. All authors have read and agreed to the published version of the manuscript.

Funding: This works has been partially supported by the research project "Construyendo Tarteso 2.0. Análisis Constructivo, Espacial y Territorial de un modelo arquitectónico en el valle medio del Guadiana" (PID2019-108180GB-100) funded by the Spanish Ministry of Science and Innovation. The funder had no role in the design of the study; in the collection, analyses, or interpretation of data; in the writing of the manuscript; or in the decision to publish the results.

Data Availability Statement: The base cartography used for this study in available at the following web links: http:/ / www.ign.es/web/ign/portal (accessed on 3 September 2021) and http:/ /ideex.es / Geoportal/pages/ideex (accessed on 3 September 2021).

Acknowledgments: The authors would like to thank the reviewers for their valuable feedback on an early draft of this manuscript.

Conflicts of Interest: The authors declare no conflict of interest.

\section{References}

1. Barrientos Alfageme, G. Introducción geográfica a la Historia de Extremadura. In Historia de Extremadura: La Geografía y los Tiempos Antiguos; Barrientos, G., Cerrillo, M., de Cáceres, E., Álvarez, J.M., Eds.; Consejería de Educación y Cultura, Junta de Extremadura: Cáceres, Spain, 1985; Volume I, pp. 13-60.

2. Celestino, S. El período orientalizante en Extremadura y la colonización tartésica del interior. In El Período Orientalizante, Actas del III Simposio Internacional de Arqueología de Mérida: Protohistoria del Mediterráneo Occidental. Anejos del Archivo Español de Arqueología; Celestino, S., Jiménez, J., Eds.; CSIC: Madrid, Spain, 2005; Volume XXXV, pp. 227-235.

3. Rodríguez González, E. El Poblamiento del Valle Medio del Guadiana Durante la I Edad del Hierro, 1st ed.; Bibliotheca Praehistorica Hispana, CSIC: Madrid, Spain, 2018; Volume XXXIV.

4. Seco Gómez, J. Dimensión social del regadío y la colonización de Vegas Altas. Revista de Historia de las Vegas Altas-Vegas Bajas 2018, 12, 87-107.

5. Sánchez Sánchez Mora, J.A. El proceso de colonización en Extremadura (1952-1975): Sus luces y sus sombras. In El Agua en Extremadura (Recursos Hídricos, Usos y Gestión del Agua); Junta de Extremadura: Badajoz, Spain, 2012; pp. $225-240$.

6. Silva, C. El proyecto arqueológico de Alqueva. Revista de Arqueología 2002, 23, 54-60.

7. Hernández Carretero, A.M. Paleoambiente y paleoeconomía en la cuenca del Guadiana durante el Hierro I. In Sidereum Ana I. El Río Guadiana en Época Post-Orientalizante, Anejos de AEsPA; Jiménez, J., Ed.; CSIC: Mérida, Spain, 2012; Volume XLVI, pp. 135-148.

8. de Tena, M.T.; Pérez, J.A.; Mayoral, V.; Martínez, J.A. Contexto geomorfológico del muestreo arqueológico en el entorno de Medellín (Badajoz). In Proceedings of the XIII Reunión Nacional de Geomorfología, Cáceres, Spain, 2-9 September 2014; pp. 40-43.

9. Mayoral, V.; Borja Barrera, F.; Borja Barrera, C.; Martínez, J.A.; Tena, M.T. The evolution of an agrarian landscape. Methodological proposals for the archaeological study of the alluvial plain of Medellín (Guadiana basin, Spain). In Landscape Archaeology between Art and Science from a Multi to an Interdisciplinary Approach; Kluiving, S.J., Guttmann, E.B., Eds.; Landscape \& Heritage Series; Amsterdam University Press: Amsterdam, The Netherlands, 2010; pp. 97-114. 
10. Ferring, C.R. Rates of fluvial sedimentation. Implications for Archaeological Variability. Geoarchaeology Int. J. 1986, 1, $259-274$. [CrossRef]

11. Bruneton, H.; Arnaud-Fassetta, G.; Provansal, M.; Sistach, D. Geomorphological evidence for fluvial change during de Roman period in the lower Rhone valley (southern France). Catena 2001, 45, 287-312. [CrossRef]

12. Arnoldussen, S. A Living Landscape: Bronze Age Settlement Sites in the Dutch River Area (c. 2000-800 BC), 1st ed.; Sidestone Press: Leiden, The Netherlands, 2008.

13. Berger, J.F. Hydrological and post-depositional impact on the distribution of Holocene archaeological sites: The case of the Holocene middle Rhône River basin, France. Geomorphology 2011, 129, 167-182. [CrossRef]

14. Chase, A.S.Z.; Chase, D.Z.; Chase, A.F. LiDAR for Archaeological Research and the Study of Historical Landscapes. In Sensing the Past; Masini, N., Soldovieri, F., Eds.; Geotechnologies and the Environment 16 Series; Springer: Cham, Switzerland, 2017; pp. 89-100.

15. Masini, N.; Coluzzi, R.; Lasaponara, R. On the Airbone LiDAR contibution in Archaeology: From site identification to landscape investigation, Laser Scanning, Theory and Applications. In Laser Scanning, Theory and Applications; Wang, C.C., Ed.; IntechOpen: Rijeka, Croatia, 2011; pp. 263-290.

16. Schindling, J.; Gibbes, C. LiDAR as a tool for archaeological research: A case study. Archaeol. Anthropol. Sci. 2014, 6, 411-423. [CrossRef]

17. Cuenca, E.C.; López, A.L. Evaluación y perspectivas del uso del LiDAR en la arqueología española. Boletín del Museo Arqueológico Nacional 2020, 39, 221-238.

18. Grau Mira, I. Archeological survey in áreas with a high density of artefacts: Analysis and interpretation proposals. Quat. Int. 2017, 435, 71-80. [CrossRef]

19. Bini, M.; Fabiani, F.; Pappalardo, M.; Schuldenrein, J. Special issue of Geoarchaeology: Urban geoarchaeology in the Mediterranean Basin. Geoarchaeology 2018, 33, 3-12. [CrossRef]

20. Fontana, A.; Ronchi, L.; Rossato, S.; Mozzi, P. Lidar-derived dems for geoarchaeological investigations in alluvial and coastal plains. Alp. Mediterr. Quat. 2018, 31, 209-212.

21. Cremaschi, M.; Storchi, P.; Perego, A. Geoarchaeology in urban context: The town of Reggio Emilia and river dinamics during the last two millennia in Horthern Italy. Geoarchaeology 2018, 33, 52-66. [CrossRef]

22. Monterroso-Checa, A. Geoarchaeological Characterisation of Sites of Iberian and Roman Cordoba using LiDAR Acquisitions. Geosciences 2019, 9, 205. [CrossRef]

23. Rondán Sevilla, I.M. El asentamiento de Puente Melchor (Puerto Real, Cádiz): Integración de fotogrametría y teledetección aérea y sus visualizaciones con resultados arqueológicos en un yacimiento de carácter litoral. Riparia 2020, 6, 30-73. [CrossRef]

24. Moterroso-Checa, A. La ubicación del santuario de Melqart en Gadir: Aportación de los datos PNOA-LiDAR. SPAL 2021, 30, 137-164. [CrossRef]

25. Cruz Sagredo, M.; López García, M. Inventario de Puentes de Extremadura. Volumen III: Badajoz, 1st ed.; Junta de Extremadura and Universidad de Extremadura: Badajoz, Spain, 2018.

26. National Geographic Institute (IGN). Available online: https:/ /www.ign.es/web/ign/portal (accessed on 3 September 2021).

27. Spatial Data Infraestructures of Extremadura (IDEEx). Available online: http://www.ideex.es/Geoportal/pages/ideex (accessed on 3 September 2021).

28. Spatial Data Infrastructure (SDI). Available online: https://www.miteco.gob.es/es/cartografia-y-sig/ide/descargas/agua/ ARPSIs.aspx (accessed on 3 September 2021).

29. LASTool Extension. Available online: https:/ / rapidlasso.com/ (accessed on 3 September 2021).

30. Relief Visualization Toolbox (RVT). Available online: https:/ /iaps.zrc-sazu.si/en/rvt\#v (accessed on 3 September 2021).

31. Almagro-Gorbea, M. Paisaje y estructuras funerarias de la necrópolis de Medellín. In Arquitecturas Funerarias y Memoria. La Gestión de las Necrópolis en Europa Occidental (ss. X-III a.c.); Adroit, S., Graells, R., Eds.; Archeologia Nuova Serie 4; Ossana Edizioni: Toulousse, France, 2017; pp. 143-166.

32. Almagro-Gorbea, M. (Ed.) La topografía de la necrópolis: Estructura y evolución. In La Necrópolis de Medellín III. Estudios Analíticos, IV. Interpretación de la Necrópolis, V: El Marco Histórico de Medellín-Conisturgis; Real Academia de la Historia: Madrid, Spain, 2008; pp. 893-906.

33. Almagro-Gorbea, M. (Ed.) Descripción de los hallazgos. In La Necrópolis de Medellín I. La Excavación y Sus Hallazgos; Real Academia de la Historia: Madrid, Spain, 2006; pp. 35-39.

34. Almagro-Gorbea, M. Medellín-Conisturgis: Reinterpretación geográfica del suroeste de Iberia. Boletim da Sociedade de Geografia de Lisboa 2008, 126, 89-115.

35. Rodríguez González, E.; Redondo Gómez, E.; Martín Becerril, M.; Guerra, S. Las evidencias arqueológicas de época calcolítica del Cerro del Castillo de Medellín (Badajoz): El sondeo 'G'. Onoba: Revista de Arqueología y Antigüedad 2017, 5, 137-170. [CrossRef]

36. Guerra, S.; Collado, H.; Pérez Romero, S.; Viola, M. "Metellinum”: Síntesis histórica y novedades arqueológicas de esta ciudad romana. In Ciudades Romanas de Extremadura; Nogales, T., Pérez del Castillo, M.J., Eds.; Museo Nacional de Arte Romano: Mérida, Spain, 2014; pp. 195-221.

37. Jiménez Ávila, J. El poblamiento en llano del Guadiana Medo durante el período post-orientalizante. In Sidereum Ana I. El Río Guadiana en Época Post-Orientalizante. Anejos del Archivo Español de Arqueología; Jiménez, J., Ed.; CSIC: Mérida, Spain, 2008; Volume XLVI, pp. 251-281. 
38. Celestino, S. Los santuarios de Cancho Roano. Del indigenismo al orientalismo arquitectónico. In Arquitectura Oriental y Orientalizante en la Península Ibérica; Ruiz Mata, D., Celestino, S., Eds.; Centro de Estudios del Próximo Oriente: Madrid, Spain, 2001; pp. 17-56.

39. Rodríguez Díaz, A. El Edificio Protohistórico de "La Mata" (Campanario, Badajoz) y Su Estudio Territorial; Universidad de Extremadura: Cáceres, Spain, 2004.

40. Celestino, S.; Rodríguez González, E. Actualidad de la investigación arqueológica en España: El yacimiento de Casas del Turuñuelo (Guareña, Badajoz). In Actualidad de la Investigación Arqueológica en España I (2018-2019); Carretero, A., Papí, C., Eds.; Museo Arqueológico Nacional: Madrid, Spain, 2020; pp. 9-27.

41. Rodríguez González, E.; García Cardiel, J. Between the Mediterranean and the Atlantic: Nautical iconography in the south-west Iberian Peninsula. Int. J. Naut. Archaeol. 2020, 49, 179-193. [CrossRef]

42. Rodríguez González, E.; Dorado, A.; Celestino, S. Las ánforas de la I Edad del Hierro del valle medio del Guadiana. In Las Ánforas Turdetanas "Tipo Macareno" Cuarenta Años Después: Actualización Tipológica y Nuevas Perspectivas; García Fernández, F.J., Sáez, A., Ferrer, E., Eds.; Editorial Universidad de Sevilla: Sevilla, Spain, 2016; In press.

43. De Jonghe, M. A propósito de la organización en las necrópolis fenicias de la Península Ibérica. In Arquitecturas Funerarias y Memorias: La Gestión de las Necrópolis en Europa Occidental (ss. X-III a.C.); Adroit, S., Graells, R., Eds.; Archeologia Nuova Serie 4; Osanna Edizioni: Toulousse, France, 2017; pp. 59-73.

44. Torres, M. El paisaje funerario de las necrópolis tartésicas. In Arquitecturas Funerarias y Memorias: La Gestión de las Necrópolis en Europa Occidental (ss. X-III a.C.); Adroit, S., Graells, R., Eds.; Archeologia Nuova Serie 4; Osanna Edizioni: Toulousse, France, 2017; pp. 359-398.

45. Fernández Flores, A.; Rodríguez Azogue, A.; Prados, E. La Necrópolis de Época Tartésica de la Angorrilla (Alcalá del Río, Sevilla); Editorial Universidad de Sevilla: Sevilla, Spain, 2014.

46. Rodríguez Díaz, A. Algunas reflexiones sobre el fin de Tartessos en la cuenca media del Guadiana: La crisis del cuatrocientos y el desarrollo de la Beturia. Cuadernos de Prehistoria y Arqueología de la Universidad Autónoma de Madrid 1994, 21, 9-34. [CrossRef]

47. Celestino, S.; Rodríguez González, E. Un espacio para el sacrificio: El patio del yacimiento tartésico de Casas del Turuñuelo (Guareña, Badajoz). Complutum 2019, 30-32, 343-366. [CrossRef] 